\title{
Bases, Bullets and Ballots: the Effect of U.S. Military Aid on Political Conflict in Colombia *
}

\author{
Oeindrila Dube $\quad$ Suresh Naidu ${ }^{\ddagger}$
}

First draft: June 2008

This draft: November 2010

\begin{abstract}
Does foreign military assistance strengthen or further weaken fragile states facing internal conflict? We address this question by estimating how U.S. military aid affects violence and electoral participation in Colombia. We exploit the allocation of U.S. military aid to Colombian military bases, and compare how aid affects municipalities with and without bases. Using detailed political violence data, we find that U.S. military aid leads to differential increases in attacks by paramilitaries (who collude with the military), but has no effect on guerilla attacks. Aid increases also result in more paramilitary (but not guerrilla) homicides during election years. Moreover, when military aid rises, voter turnout falls more in base municipalities, especially those that are politically contested. Our results are robust to an instrument based on worldwide increases in U.S. military aid (excluding Latin America). The findings suggest that foreign military assistance may strengthen armed non-state actors, undermining domestic political institutions.
\end{abstract}

\footnotetext{
${ }^{*}$ We are grateful to Michael Clemens, Jorge Dominguez, Jesse Driscoll, Arin Dube, Andrew Gellman, Lawrence Katz, Sendhil Mullainathan, Rohini Pande, Dani Rodrik, Shanker Satyanath, and workshop participants at UC Berkeley, Johns Hopkins SAIS, Columbia, UIO, Harvard, UC San Diego, the Center for Global Development, the World Bank and Yale for useful comments. We also thank Fabio Sánchez, Juan Vargas and Maria Cecilia Acevedo Villalobos for helping us access data used in this paper. All errors are our own.

${ }^{\dagger}$ New York University. Contact: odube@nyu.edu.

$\ddagger$ Columbia University. Contact: sn2430@columbia.edu.
} 


\section{Introduction}

Around the world, advanced countries expend vast resources with the putative goal of building capable, democratic states in developing countries. Military aid from the United States and other advanced nations exceeds all other forms of foreign aid, including development assistance. ${ }^{1}$ From contemporary Iraq, Mexico, and Afghanistan to historical Cold War client states such as Zaire, a large amount of military assistance has been deployed in the claimed interest of shoring up weak states against insurgents, drug cartels and other armed, non-state actors. Knowing whether this foreign military assistance achieves its intended objective is thus of immediate importance to both academics and policymakers. Yet the impact of military aid on domestic political outcomes has been relatively under-studied, particularly by quantitative researchers.

This paper employs micro-level data to estimate the impact of U.S. military aid on political conflict in Colombia. Specifically, we assess how military assistance has affected violence and democracy, as measured by participation in elections, over 1988-2005. The Colombian civil war represents a decades old conflict between left-wing guerillas, the state, and right-wing paramilitary groups, which have been known to collude with the government military in countering the guerilla. It serves as the ideal laboratory for studying this question since both of the armed non-state actors, guerillas and paramilitaries, seek territorial dominance via warfare and electoral manipulation. Moreover, over the past two decades, the United States has provided nearly $\$ 5$ billion in military aid, with the stated aim of supporting counter-narcotics and counter-insurgency efforts. To analyze how U.S. military aid affects conflict dynamics, our empirical strategy takes advantage of the fact that U.S. military aid is allocated to brigades of the Colombian armed forces, which operate out of military bases located in particular municipalities. This generates within-country spatial variation in the allocation of foreign military assistance, allowing us to estimate whether annual changes in U.S. military aid affect political outcomes differentially in municipalities that have military bases, relative to those that do not.

The Colombian context is of general interest for scholars interested in the interplay between domestic political development and international aid. Empirical evidence from conflict-ridden states such as Colombia is important because it is theoretically unclear whether an underdeveloped state is made stronger by an infusion of military or financial resources. While a weak state may benefit from external military assistance if it strengthens the state's repressive capacity

\footnotetext{
${ }^{1}$ For example, in 2008, the United States allocation for development aid, including official development assistance, USAID administrative expenses and the State Department Economic Support Fund, totalled 4.7 billion dollars. In contrast, 5.2 billion was allocated for military aid to other countries, including Foreign Military Financing, International Military Education and Training and the Andean Counter-Drug Initiative (Congressional Budget Justification, 2008).
} 
vis-a-vis non-state armed groups (Fearon and Laitin, 2003), the very weakness of the state may also enable substantial capture and diversion of given resources (Jackson, 1990). Via this second channel, donor countries may find themselves fueling the very groups that military aid is designed to suppress. The results in this paper present evidence of this form of diversion: the findings suggest that military and counter-narcotics aid to Colombia, rather than enhancing the state's monopoly on the legitimate use of violence, is diverted to empower non-state armed actors, increasing both extra-legal violence and electoral manipulation, with no apparent reduction in drug production.

Our estimates display a distinct, asymmetric pattern: when U.S. military aid increases, attacks by paramilitaries, who are known to work with the military, increase more in municipalities with bases. However, there is no significant effect on guerilla attacks. Moreover, there is a disproportionate increase in paramilitary homicides in base regions during election years, but no equivalent increase in guerilla homicides. In addition, the aid shock has no significant effect on the cultivation of coca, the crop used to manufacture cocaine. In terms of electoral participation, when military aid rises, voter turnout falls more in the base municipalities, and these effects are larger in municipalities that are politically contested, either militarily or electorally. The estimates imply substantial effects: a $1 \%$ increase in US military assistance increases paramilitary attacks by $1.5 \%$ more in base municipalities, and lowers turnout for mayoral elections by $.2 \%$ and $.12 \%$ more in militarily and electorally contested regions, respectively. These results are consistent with the idea that the influx of foreign military aid enhances the capacity of paramilitary groups, both to carry out political attacks, and to intimidate voters, which reduces political participation.

To address potential endogeneity in the timing of U.S. military aid we use an instrumental variables strategy which exploits general increases in U.S. military spending around the world (excluding Latin America). The rise in global U.S. military aid reflects the broad geopolitical outlook of the American government shaped by major world events such as 9/11, and can thus be considered exogenous to the Colombian conflict. Since periods of high foreign aid may also be correlated with periods when the Colombian state prioritizes defense, we additionally control for the size of the Colombian government military budget and indicators of which presidential administration is in power over different sub-periods. Moreover, we are able to control for historical violence levels, to account for the possibility that base municipalities may have become flashpoints in the armed struggle and display greater violence responsiveness relative to non-base municipalities.

Our results suggest that foreign aid may strengthen armed, non-state actors in an environment where there are ties between the government military and these other groups. Indeed, non-democracy and sustained civil wars have been held as a persistent legacy of superpower backing of armed groups in the Cold War era (Westad 2006, Easterly et al. 2008). The idea 
that external funding may sustain conflict by financing armed non-state actors has relevance to several other major contemporary recipients of US military aid, such as Iraq and Afghanistan, where armed militias maintain deep links to the U.S. trained and equipped military. Diversion of ammunition to non-state actors has been documented by the Small Arms Survey in a number of countries. In contemporary Afghanistan, U.S. commanders acknowledge that substantial amounts of U.S. military equipment falls into the hands of anti-U.S. insurgent groups including the Taliban. ${ }^{2}$

Our paper is situated within the broader literature on the economic determinants of insurgency. A number of cross-country studies have found a negative relationship between GDP and the probability a nation experiences civil war, including Collier and Hoeffler, 1998 and 2004; Fearon and Laitin, 2003; Miguel et al., 2004; and Fearon, $2005 .{ }^{3}$ Several within country analyses also examine the relationship between income and violence, including Angrist and Kugler, 2008; Deininger, 2003; Barron et al., 2004; Do and Iyer, 2007; and Hidalgo et al, (forthcoming). This literature suggests that the effect of income on conflict is highly heterogeneous, depending on the source and type of income. For example, Dube and Vargas (2008) find that rising agricultural export prices reduce violence by raising workers' wages and the opportunity costs of joining armed groups while rising natural resource prices increase violence by increasing rents available for capture.

Another strand of the economic determinants literature has focused on insurgency and state capacity, particularly the provision of public goods. Fearon and Laitin (2003) suggest that the cross-country negative correlation between income and conflict is driven by lower state capacity, in particular the state's ability to inhibit rebellion. Berman and Laitin (forthcoming) show that when the state fails to provide public goods, radical religious groups providing these social services are able to carry out more lethal forms of terrorist attacks. Berman et al. (2009) also find that spending on local public goods can reduce insurgency, using data from reconstruction spending in Iraq.

Foreign aid may potentially affect both income and state capacity, and thus civil conflict, but the direction of the effect may be positive or negative. Theoretical papers focusing on the relationship between aid and conflict have posited both signs. Grossman (1992) suggests that aid increases conflict by expanding the rents available for capture. However, Collier and Hoeffler (2002) suggest that aid may reduce civil conflict either by increasing the state's capacity to repress conflict, or by encouraging economic growth and diversification of income sources, which subsequently reduces conflict.

Likewise, empirical assessments of the relationship between aid and conflict have also found

\footnotetext{
${ }^{2}$ New York Times. May 19, 2005. "Arms Sent by U.S. May Be Falling Into Taliban Hands."

${ }^{3} \mathrm{~A}$ comprehensive review is beyond the scope of this paper, but Sambanis (2002) provides a survey of this literature.
} 
different results. Collier and Hoeffler (2007) show that aid increases military expenditures and exacerbates regional arms races between neighboring countries. However, de Ree and Nillesen (2009) find that increases in foreign aid decrease the likelihood of civil wars, using donor country GDP as an instrument for foreign aid to countries in Sub-Saharan Africa.

Our paper is also related to the broader cross-country literature which analyzes how foreign aid affects domestic political institutions. For example, Morrison (2009) finds that foreign aid, as a type of non-tax revenue for the state, increases political stability in both dictatorships and democracies. Wright (2009) shows that conditional aid can promote democratization in dictatorships maintained by large coalitions. Goldsmith (2001) and Dunning (2004) find small but significant, positive effects of aid on democracy in Africa. In contrast, Knack (2004) reports no significant impact of foreign aid on democracy, and Djankov et al. (2008) report a negative effect of aid on democracy and institutional quality, using initial income and strategic interest variables as instruments for aid. Other studies have demonstrated that aid can increase corruption (Svensson, 2000); the size of government (Remmer, 2004); and the income share of the rich (Bjornskov, 2009), in some nations.

Most previous studies in these literatures have not distinguished between military and other types of foreign aid, and there has been little empirical analysis of how military assistance affects either institutions or violence. Yet focusing specifically on military aid facilitates testing whether the repressive capacity channel reduces conflict in a way that analyzing aggregate foreign aid does not. One exception is Finkel et al.(2009), which finds no significant effect of military aid on democracy in a panel of countries. However, the objective of the Finkel et al. study is not to identify the effect of military aid, which is used as a control variable, and the estimated effect cannot be interpreted in a causal manner.

Finally, our paper is also related to Acemoglu et al. (2010), which examines the role of paramilitary groups in influencing national elections in Colombia, by assessing their effect on partisan votes and electoral competition. Although the focus of our analysis is the effect of external military aid on paramilitary groups, our finding that the aid shock increases paramilitary violence and reduces electoral turnout in regional elections is consistent with evidence of electoral manipulation presented in Acemoglu et al. (2010).

Our paper is the first empirical assessment of how foreign military aid affects both civil war and democracy in a within-country context. The use of detailed within-country data enables us to exploit geographic variation across Colombian municipalities in terms of access to U.S. military aid, as well as variation over time in the amount of U.S. military aid. This enables cleaner identification of the political consequences of foreign military assistance. The remainder of the paper is organized as follows: Section 2 provides background; Section 3 describes the empirical strategy; Section 4 details the data; Section 5 presents results; and Section 6 concludes. 


\section{Background}

In this section we provide background on the Colombian conflict, U.S. military assistance to Colombia and the relationship between the government military and paramilitary groups.

\subsection{The Colombian Civil War}

The Colombian conflict started in the 1960s with the launch of a communist insurgency. Officially, it is a three-sided conflict among the communist guerillas, the government and right-wing paramilitary groups. However, as we document below, the paramilitaries work informally with the government in countering the guerilla. The current-day insurgency is led by the Armed Revolutionary Forces of Colombia (FARC by its Spanish acronym), whose strength at the time of the analysis was roughly 16,000-20,000 combatants, and the National Liberation Army (ELN), which was estimated to have 4,000-6,000 fighters (both have since seen their membership fall). Both groups fight with the stated aim of overthrowing the government, but also claim to represent the rural poor by supporting policies such as land redistribution.

Although paramilitarism also dates back to the 1960s, paramilitary groups in their current form emerged during the 1980s, as private armies for drug cartels and large landowners who were targeted for extortion by the guerillas. In 1997, the disparate paramilitary groups formed an umbrella organization called the United Self-Defense Forces of Colombia (AUC), which had roughly 30,000 fighters at its peak strength. In 2003, the AUC declared a partial cease-fire, and some paramilitary blocks agreed to participate in a demobilization program sponsored by the Organization of American States. However, the demobilization did not effectively disarm all the paramilitary units. Thus, in 2005, when the Colombian congress proposed a bill allowing extradition of paramilitaries, the AUC could credibly threaten renewed violence. ${ }^{4}$ More generally, despite the official demobilization, human rights groups have documented continued paramilitary violence, which in part reflects the formation of a new generation of paramilitary groups, as well as renewed violence by members of pre-existing paramilitary groups. ${ }^{5}$

Although the paramilitaries and guerillas pursue kidnapping, extortion, and predation on natural resource rents, both groups rely largely on the cocaine drug trade for financing purposes. Thus the drug trade is inextricably linked to the dynamics of internal conflict.

\footnotetext{
${ }^{4}$ BBC News. April 11, 2005. "Paramilitary Fighters Reject Amnesty."

${ }^{5}$ See "Evaluation of the Paramilitary Demobilization in Colombia," 2006 conference proceedings from Corte a Impunidad - Colombia en la Mira de la Corte Penal Internacional. http://www.kolko.de/downloads/evaluation_demobilization.pdf
} 


\subsection{U.S. Aid to Colombia}

Owing to its position as the world's largest producer of cocaine, Colombia has become a major recipient of U.S. military assistance over the past two decades. Throughout the 1990s it was the third largest recipient after Israel and Egypt, and today, ranks fifth in the list inclusive of Iraq and Afghanistan. Colombia started receiving more aid geared toward drug-eradication when the "War on Drugs" was initiated during the late 1980s. The 1990 "Andean Initiative" provided Colombia with a $\$ 200$ million aid package intended to combat drugs, but comprised largely of resources to train and equip the Colombian military (Isaacson, 2005). Official aid fell sharply in 1994, when President Ernesto Samper, who had a very hostile relationship with the U.S., was elected to office in Colombia. However, with the advent of the new Pastrana administration in Colombia in 1998, the United States started developing "Plan Colombia", a $\$ 1.2$ billion aid package launched in 2000. This aid package was again aimed at training and equipping the Colombian military for counter-narcotics operations, rather than pursuing counter-insurgency. However, given the guerillas involvement in the drug trade, the line between these two objectives has remained blurry, and it is impossible to distinguish the counter-narcotics and counterinsurgency components of U.S. aid. For this reason, we define military aid to Colombia as the sum of these two line-items, and analyze this aggregate category throughout the paper.

One important characteristic of US military aid is that it is disbursed to particular military brigades, each of which is attached to and operates out of a particular government military base. This disbursement method serves as the basis of our identification strategy, since regions with military bases receive more aid. Given the well-documented history of Colombian military human rights abuses, some jointly executed with paramilitary units, U.S. lawmakers have attempted to restrict disbursement to military units that have been recorded as committing human rights violations. In 1997 the United States Congress passed the "Leahy Amendment", which required Colombian military brigades to be vetted for human rights abuses before becoming eligible for US assistance. However, the Colombian armed forces have evaded this clause through three mechanisms: first, by reshuffling individuals accused of human rights violations across brigades; second, by forming new brigades, which were subsequently vetted and "approved" by the U.S. State Department; and third, by not cooperating in handing over information about human rights violations to the U.S. government. ${ }^{6}$ Moreover, the Plan Colombia package was specifically exempted from having to abide by the human rights clauses of the Leahy provision. ${ }^{7}$

\footnotetext{
${ }^{6}$ National Security Archives Declassified document archive: http://www.gwu.edu/〜nsarchiv/NSAEBB/NSAEBB69/col58.pdf last accessed: $4 / 29 / 09$

${ }^{7}$ The Washington Post, Aug. 23, 2000, "Clinton Clears Aid Package For Colombia; Human Rights Waiver Allows $\$ 1.3$ Billion to Fight Drugs."
} 


\subsection{Links Between the Colombian Military and Paramilitaries}

In this section, we document the links between the Colombian military and paramilitary groups. Historically, there have been three periods when the Colombian state officially sanctioned the creation of civilian networks that came to function as paramilitaries. However, in more recent years, paramilitarism has been made illegal, and collusion between the military and paramilitary groups has taken a tacit form.

While rural Colombian elites had organized local self-defense units during La Violencia, organized paramilitarism emerged in the 1960s as a result of attempts by the Colombian military to enlist civilian support through "Plan Lazo," which authorized the creation of civil patrols armed by the Defense Ministry (Hristov, 2000). ${ }^{8}$ The 1980s saw the rise of a new type of paramilitary group, the private armies of drug lords and the rural elite who opposed the guerillas. These groups did not receive state support, but did receive assistance from military and police officers through unofficial channels. For example, in 1983, the Colombian attorney-general noted that a sizeable number of the crimes committed by the paramilitaries were committed by "active police and military officers (ibid)." In 1991, there was a second state-sanctioned effort: the Colombian Intelligence agency engineered a reorganization which mandated the creation of informal civilian networks that would relay information to the military. Many of these networks were subsequently found to have worked with paramilitary groups. ${ }^{9} 10$ Finally, the CONVIVIR effort of 1994 created rural security cooperatives that were armed with equipment from the Colombian military (Hristov, 2009, p. 69). However, the rapid growth in violence associated with CONVIVIR networks led to a sharp reversal of policy in 1997, when these groups were reigned in by the Judiciary, and effectively declared illegal. Nonetheless, some of the CONVIVIR continued operating as illegal paramilitary groups during the 1990s, and the marriage of these networks with the private armies of the 1980s led to the paramilitary groups of the late-90s, united under the banner of the AUC.

Although official state government support was withdrawn after 1997, and the judiciary began prosecuting politicians and military officials for ties to these groups, collusion between the AUC and military continued throughout the 1990s and 2000s. This is reflected in the recent indictment of several high-level military officials. In 2006, General Mario Montoya, the

\footnotetext{
${ }^{8}$ This was a joint initiative between U.S. and Colombian counter-insurgency efforts. Decree 2298 authorized the executive branch to create civil patrols and directed the Defense Ministry to arm and supply these patrols (Hristov, 2000, pg. 62).

${ }^{9}$ Human Rights Watch. 1996. "Colombia's Killer Networks: The Military-Paramilitary Partnership and the U.S."

${ }^{10}$ An an example, the Barrancabermeja Network was created by the Navy in response to Order 200-05/9. This network later worked with MAS, a paramilitary group accused of perpetuating atrocities during the early 1990s. Human Rights Watch reports that "In partnership with MAS, the navy intelligence network set up in Barrancabermeja adopted as its goal not only the elimination of anyone perceived as supporting the guerrillas, but also members of the political opposition, journalists, trade unionists, and human rights workers, particularly if they investigated or criticized their terror tactics (HRW, 1996)."
} 
commander (and highest ranking officer) of the Colombian army, was charged with supplying weapons to paramilitaries while stationed in a military base in Medellin. Six other high ranking members of the intelligence and armed forces were also indicted by the Colombian supreme court on suspicion of collusion with paramilitaries in 2008. This includes the former director and deputy director of the Administrative Security Department (a key security agency), as well as former army commanders and active colonels. ${ }^{11}$

Human rights organizations have documented the specific channels through which the Colombian army provides military and logistical support to the paramilitaries, which includes: intelligence sharing; supply of weapons and transport equipment; training; exchange of suspected guerilla sympathizers for torture and execution; assistance in paramilitary operations; and the conduct of joint operations. ${ }^{12}$

For example, Human Rights Watch (HRW) reports that military intelligence has provided paramilitaries with lists of suspected insurgents or guerrilla sympathizers, who are then threatened or killed by paramilitaries. ${ }^{13}$ Interviews with ex-military intelligence officials suggest that the sale of military arms to paramilitaries was common. ${ }^{14}$ Ex-paramilitaries have also described using military helicopters, and being flown in to military bases. ${ }^{15}$

Support for paramilitary operations has taken both indirect and direct forms. For example, the army general in Mapiripán, in Meta department, ordered his troops to stay out of the area and not intervene during a paramilitary massacre. In other cases, the military has provided road blockades while the paramilitaries conduct massacres. There are also many examples of joint operations between the military and paramilitaries. For example, the Captain of the 17th Brigade was charged with masterminding the San José de Apartadó massacre in 2005. ${ }^{16}$ As another example:

In sworn testimony to Attorney General investigators taken on April 30, 1998, Francisco Enrique Villalba Hernández, a former paramilitary who took part in the El Aro massacre, confirmed the testimony by survivors taken by Human Rights Watch that the operation had been carefully planned and carried out by a joint paramilitaryArmy force. ${ }^{17}$

The provision of support is in part facilitated by overlaps in networks of the military and

\footnotetext{
${ }^{11}$ The list of accused is available at http://www.colombiasupport.net/news/2007/05/hundreds-of-publicservants-implicated.htm, last accessed: 10/24/09.

${ }^{12}$ Human Rights Watch. 2000. "The Ties That Bind: Colombia and Military-Paramilitary Links."

${ }^{13}$ HRW, 1996.

${ }^{14}$ HRW, 2000.

${ }^{15}$ La Semana, Nov. 18, 2008. "Former paramilitary leader Salvatore Mancuso said that AUC received help from the police and the military in massacre."

${ }^{16}$ El Spectator, Aug. 1 2008. "Verdades de la masacre de San José de Apartadó."

${ }^{17}$ HRW, 2000.
} 
paramilitary groups. For instance, Human Rights Watch details the military's involvement with a paramilitary group called the "Calima Front:"

Third Brigade active duty and reserve officers formed the Calima Front, with the assistance of Carlos Castaño [then head of the AUC]. Active duty officers provided intelligence and logistical support. Former military officers were among those called in to assume positions of command. ${ }^{18}$

These links have raised concern among American policymakers that some part of U.S. aid may end up providing operational or material support to paramilitaries, through factors such as weapons supply. In 2000, a declassified cable from Secretary of State Albright to Ambassador Kammen indicated: "We note with concern persistent reports that the 24 th Brigade, and the 31st Counterguerrilla Battalion in particular, has been cooperating with illegal paramilitary groups that have been increasingly active in Putumayo."19 A U.S. Military Advisory Group inquiry in 1995 revealed that military brigades associated with joint human rights violations with paramilitaries had received military assistance, including "vehicles, M6 and M60E3 machine guns, pistols, grenade launchers, $7.62 \mathrm{~mm}$ and $9 \mathrm{~mm}$ ammunition, and claymore mines'."20 More recently, even direct examples of weapons supply have emerged. For example, in 2005, the Colombian government arrested two U.S. army officers near Melgar, Tolima, the site of one of the largest bases in Colombia, under charges of arming paramilitary groups with ammunition supplied by the U.S. government. ${ }^{21}$

The bases through which brigades operate often play a key role since proximity to the base can facilitate the military's provision of material and operational support to paramilitary groups. Since U.S. military aid is allocated to brigades operating from the bases, they represent the physical points of diffusion for US military assistance.

\section{Empirical Strategy}

Our empirical strategy uses the fact that U.S. military aid is allocated to brigades which are headquartered in military bases located in particular municipalities. This creates spatial variation in the allocation of U.S. military aid across municipalities. Importantly, these are longstanding military bases that precede the period of the analysis. This precludes the possibility

\footnotetext{
${ }^{18} \mathrm{HRW}, 2000$.

${ }^{19}$ National Security Archive:

http://www.gwu.edu/ nsarchiv/NSAEBB/NSAEBB69/col70.pd

last accessed: 10/24/09

${ }^{20} \mathrm{HRW}, 1996$.

${ }^{21}$ New York Times, May 5, 2005, "Ammo Seized in Colombia; 2 G.I. Suspects Are Arrested."
} 
that they have been constructed as an endogenous response to political or conflict dynamics for the period of our analysis. Our empirical strategy assesses how changes in U.S. military aid affect violence and electoral outcomes in regions with military bases, relative to municipalities without bases.

We implement a basic difference-in-differences estimator, controlling for municipality and year fixed effects in a linear regression. Municipality fixed effects control for all time-invariant municipality characteristics that may be correlated with conflict, including geographic features such as rough terrain, the presence of the base itself, and historical conditions of the municipality. Year effects also control for conflict levels that are common to all Colombian municipalities in a given year, including those influenced by international and national political or economic factors. Thus, we estimate:

$$
y_{j t}=\alpha_{j}+\beta_{t}+\left(\text { USmil }_{t} \times \text { Base }_{j}\right) \lambda+\mathbf{X}_{j t} \phi+\omega_{j t}
$$

where $\alpha_{j}$ are municipality fixed effects and $\beta_{t}$ are year fixed effects. $y_{j t}$ are either electionsrelated variables including voter turnout, or conflict related variables including the number of paramilitary attacks, government attacks, or guerilla attacks in municipality $j$ and year $t$. $\mathbf{X}_{j t}$ is a vector of control variables which varies across specifications but always includes the natural log of population, which controls for the scale effect since our conflict-related dependent variables are the number of attacks. Base ${ }_{j}$ is a dummy variable which equals one if the municipality has a military base. USmil $t_{t}$ is the natural log of U.S. military aid to Colombia. The coefficient $\lambda$ captures the extent to which changes in military assistance induce a differential change in violence in municipalities that have bases, relative to non-base municipalities. The municipality fixed effects $\alpha_{j}$ control for Base $_{j}$ and the year effects $\beta_{t}$ control for the overall level of USmil $l_{t}$, which is why the constituent terms of the interaction do not appear separately. Equation (1) is estimated using OLS, with all standard errors clustered at the municipality level.

One concern with this empirical strategy is potential endogeneity in the timing of U.S. funding. If U.S. military assistance responds to differential growth in violence across Colombian municipalities, then this could confound estimates of equation (1). This reverse causality would generate an upward bias if U.S. military aid increases more in response to violence growth in municipalities with military bases. For instance, attacks in base regions may be viewed as a strong threat to stability, and therefore galvanize more US funding relative to attacks in other regions. On the other hand, reverse causality may generate a downward bias if U.S. assistance increases more in response to violence growth in non-base regions. As an example, since reducing narcotics production is a stated U.S. objective, military aid may respond to violence increases in the largest coca producing municipalities, which are non-base municipalities.

To address this potential endogeneity, we use an instrumental variables strategy which uses 
changes in U.S. funding in countries outside of Latin America as an instrument for changes in U.S. funding to Colombia. Since Colombia is one of the largest recipients of U.S. anti-narcotics assistance, it is possible that the allocation of this line-item to Colombia determines the allocation of anti-narcotics assistance to other countries. To avoid this concern, we instrument the sum of anti-narcotics and military aid to Colombia solely with military aid to other nations. U.S. funding to the rest of the world is determined by the broad geopolitical outlook of the American government, reflecting factors such as the party of the president or other major world events, and can thus be considered exogenous to conflict dynamics in Colombia. For example, Figure 1 shows that there was a sharp increase in U.S. military assistance to countries outside of Latin America after 2001. This reflects both the start of the Bush administration, and the events of 9/11, which created an impetus to provide greater funding as a part of the "war on terror." This figure also shows that U.S. assistance to Colombia is positively correlated with military aid to non-Latin American nations. Indeed, a simple regression of these two time series confirm that there is a significant positive relationship. We present this estimate in the Supporting Information Appendix (Table A.I), which also shows that this relationship is robust to the inclusion of a linear time trend. Since our treatment is the interaction of U.S. military aid with the military base indicator, our instrument is aid to non-Latin nations interacted with the base indicator. The first stage is given by:

$$
\text { USmil }_{t} \times \text { Base }_{j}=\alpha_{j}+\beta_{t}+\left(\text { USmilnonlac }_{t} \times \text { Base }_{j}\right) \gamma+\mathbf{X}_{j t} \rho+v_{j t}
$$

where USmilnonlac $t_{t}$ is the log of U.S. military aid to non-Latin American countries. The second stage is given by:

$$
y_{j t}=\alpha_{j}+\beta_{t}+\left(\text { USmil }_{t} \widehat{\times B} \text { Base }_{j}\right) \delta+\mathbf{X}_{j t} \eta+\omega_{j t}
$$

We also assess whether there are differential effects of the aid shock during election periods. To analyze this, we estimate:

$$
y_{j t}=\alpha_{j}+\beta_{t}+\left(\text { USmil }_{t} \times \text { Base }_{j} \times \text { Ele }_{t}\right) \theta+\left(\text { USmil }_{t} \times \text { Base }_{j}\right) \lambda+\left(\text { Ele }_{t} \times \text { Base }_{j}\right) \vartheta+\mathbf{X}_{j t} \phi+\omega_{j t}
$$

where $E l e_{t}$ is a dummy which equals one during the years in which elections were held in Colombia: 1988, 1990, 1991, 1994, 1997, 1998, 2000, 2002 and 2003. The coefficient $\theta$ captures the differential effect of US military spending in base regions during election years relative to non-election years. The coefficient $\vartheta$ captures the differential effect of election periods on violence in base regions relative to non-base regions. All other two-way sub-interactions are absorbed by the municipality or year fixed effects. 


\section{Data}

\subsection{Data Sources}

Our data on civil war violence comes from the Conflict Analysis Resource Center (CERAC). This dataset is event-based, and includes over 21,000 war-related episodes in over 950 municipalities from 1988 to 2005. It is collected on the basis of 25 major newspapers and supplemented by oral reports from members of Catholic social networks who track human rights violations. Since the clergy operates in every municipality of Colombia, this expands the scope of coverage of our data to remote regions that may otherwise lack media coverage. The priests are regarded as neutral actors in the conflict, and often used as negotiators between the two sides. This minimizes potential over-reporting of violent events perpetuated by one side over another. The data is also cross-checked against other official sources, including a dataset by the National Police and reports by Human Rights Watch and Amnesty International. The procedure used to collect the data is described more extensively in Restrepo et al. (2004).

The CERAC data records the number of attacks that are undertaken by each major actor in the conflict, including the government, the paramilitaries, the guerillas, which are the main dependent variables of our analysis. The data is able to distinguish between unilateral attacks, which are one-sided events carried out by a particular group, versus two-sided events involving an exchange of fire among two or more groups. We use the data on clashes to develop measures of whether a municipality is contested militarily during particular years of our sample period.

We also employ a number of conflict-related variables from a dataset by the Center for Study of Economic Development (CEDE), which was collected from the Observatory of Human Rights of the Vice-Presidency of Colombia. This data is based on reports from the Colombian security agency, the Administrative Department of Security. This annual level dataset gives us a measure of the number of homicides undertaken by paramilitaries and guerillas in each municipality, as well as homicides of elected officials, candidates running for office, and community leaders, which we refer to as assassinations. It also includes a number of other measures of paramilitary and guerilla activity, including variables such as population displacement and pirating undertaken by armed groups. Finally, the CEDE data also provides detailed measures of the number of government military actions undertaken in each municipality, including rescue of kidnaps, deactivation of explosives, and seizure of arms and captives, as well as anti-narcotics operations and the dismantling of narcotics laboratories. These variables enable us to discern whether the inflow of US military assistance induces greater government actions in narcotics related areas, versus other counter-insurgency areas. We define our core sample based on the number of municipalities which include both the CERAC and CEDE conflict data, which gives us a sample of 936 municipalities. 
In addition, we analyze electoral outcomes using data from the National Registry, the official Colombian government electoral agency. We look at local elections, including elections for mayor and town councils, (where candidates run at the municipal level), as well as for governor and the state assembly (where candidates run at the department, or state level). Municipal level data on voter turnout that is comparable across years is only available for 2000 and 2003, which is the sample for our elections results. However, we also use the aggregate vote shares for mayoral candidates in the 1997 election to classify municipalities as electorally contested in this year.

We construct an indicator of whether a municipality has a military base from two sources. First, we begin with the base locations reported in globalsecurity.org, which gives us a list of 37 municipalities with military bases. We cross-check each of these bases against information from the Colombian army, navy and airforce websites to determine which bases were newly built over our sample period. ${ }^{22}$ We find three new bases, and exclude them from the sample, since it is possible that these bases were built as an endogenous response to conflict dynamics. ${ }^{23}$ This leaves us with 34 municipalities with military bases, of which 32 appear in the sample for which the conflict data is available. Map 1 shows the location of these bases.

We obtain data on a number of municipal level characteristics from CEDE, including time varying measures such as population, and time invariant characteristics such as the average height of the municipality. In addition, we obtain data on coca cultivation from two sources. Dirección Nacional de Estupefacientes (DNE) has a measure of land used for coca cultivation in each municipality in 1994. An equivalent measure for 1999 to 2004 comes from the United Nations Office of Drug Control (UNODC), which collects this data based on satellite imagery.

Finally, we use the USAID Greenbook for data on US aid. Since much of US assistance to Colombia, including the provision of training and equipment, falls under the category of anti-narcotics assistance, we look at the combined categories of military and anti-narcotics assistance. For our instrumental variables strategy, we also use Greenbook data on military assistance in other countries outside of Latin America. In addition, we use data on development assistance to Colombia, which includes assistance provided by USAID and the Economics and Support Fund (ESF) of the State Department.

\subsection{Descriptive Statistics}

Table I shows the descriptive statistics of key variables, in municipalities with and without military bases. The means indicate that paramilitary, guerilla and government attacks tend to be higher, on average, in base municipalities relative to non-base municipalities. Our identification

\footnotetext{
${ }^{22}$ The army website (last accessed 4/10/09): http://www.ejercito.mil.co/?idcategoria=69

The navy website (last accessed 4/10/09): http://www.armada.mil.co/

The air forces website (last accessed 4/10/09): http://www.fac.mil.co/?idcategoria=391

${ }^{23}$ These are the bases at Carepa, Tres Esquinas, and Larandia.
} 
strategy estimates whether there are differential increases in base regions when US military aid increases. In contrast, the paramilitary and guerilla political assassination variables are lower in the base municipalities relative to the non-base municipalities. The empirical estimates seek to identify whether there are differential increases in these outcomes in base regions during election periods, relative to non-election periods. It is worth noting that the mean paramilitary assassinations is higher than mean guerilla assassinations in both types of regions, which is consistent with the anecdotal evidence that paramilitary groups use this type of targeted political violence with greater frequency.

In terms of municipal level characteristics, the standard deviation of height, which measures ruggedness of the terrain, shows that non-base municipalities are more rugged. We consider this factor in the analysis since ruggedness has been shown to be correlated with internal conflict. The indicator for whether coca was produced shows that roughly a quarter of the non-base regions and one-third of the base locales were recorded as producing coca at some point over the sample period, and the hectares of land used for cultivating coca in 2000 was even higher on average, in base regions. In addition, a higher fraction of base municipalities also either produce oil or have oil pipelines. Given these differences, we interact all of these municipal characteristics with year effects and employ them as time varying controls for robustness in the analysis below.

\section{Results}

\subsection{U.S. Military Aid and Violence in Base Municipalities}

We begin with a simple graph which captures the essence of our empirical strategy. We interact our base indicator with year dummy variables, and regress paramilitary attacks on these interaction terms, controlling for municipality and year fixed effects and the log of population. In Figure 2, we graph the coefficients on the year-base interactions along with US military and narcotics aid to Colombia. The figure shows that the coefficients and aid time series move in tandem during most years. In particular, differential attacks increase in 2000 when Plan Colombia was launched, fall in 2001 when military aid was scaled down and rise again in 2002 when aid started increasing. ${ }^{24}$

\footnotetext{
${ }^{24}$ We posit that differential attacks fell in 2004 due to the paramilitary demobilization of 2003 , which resulted in a drastic reduction of paramilitary attacks, particularly those undertaken by the AUC. Since the AUC is the most politically connected faction of the paramilitary groups with most direct links to the military, this suggests that the sharp fall in AUC attacks nation-wide also reduced the differential number of attacks between base and non-base municipalities. However, as discussed in Section 2.1, the demobilization resulted in a temporary hiatus of attacks, and paramilitary violence resumed once again in 2005, including renewed violence by former blocks of the AUC. Our data corroborate anecdotal evidence around renewed violence, showing that the number of attacks spiked upward this year after falling in 2003 and 2004.
} 
Table II confirms this visual impression with OLS estimates of equation (1). Columns (1)(3) show that an increase in military assistance significantly increases government attacks and paramilitary attacks in base regions relative to non-base regions, but has no significant effect on guerilla attacks. This asymmetric effect between paramilitary and guerilla attacks is one of our key findings. It suggests that U.S. military aid has a differential effect in terms of strengthening paramilitary capacity rather than guerilla capacity, and is consistent with the idea that aid channeled through the Colombian military specifically reaches paramilitary groups. The noneffect on guerillas also presents evidence against the idea that aid is targeted to regions that have high overall levels of civil war violence.

The estimates imply substantial effects: the coefficient of .148 in column (1) suggests that a $1 \%$ increase in U.S. aid increases paramilitary attacks by approximately .0015 more in base municipalities, or by $1.5 \%$ more above the mean paramilitary attacks of .103 over the sample period. Similarly, column (2) implies that $1 \%$ more aid increases government attacks by approximately $1 \%$ more in base versus non-base areas. U.S. aid to Colombia increased by an average of $92 \%$ per year, over 1988-2005. Thus, our estimates imply an associated differential increase of $138 \%$ in paramilitary attacks and $92 \%$ in government military attacks.

Armed groups may try to capture many types of local resources, so if base municipalities also receive other forms of aid, then paramilitary violence may increase because of a general rise in resources flowing to the region, rather than an increase in military aid per se. To test this alternative channel we undertake a falsification exercise in columns (4)-(6). We analyze whether changes in U.S. development assistance affect violence differentially in municipalities with bases. The coefficients on the interaction of the base indicator with development assistance is statistically indistinguishable from zero for all three outcome variables, which helps rule out this alternative account.

In columns (1)-(3) of Table III, we control for this type of change by including a department $^{25}$ by year fixed effect, which compares only municipalities within the same department, within the same year. This sweeps out all variation at the department year level which may be correlated with both violence and military aid, such as security-related department policies or other types of aid targeted to departments. Although the coefficient on the aid interaction becomes insignificant for the government attacks variable, it remains significant for the paramilitary attack outcome, suggesting a robust effect of US military aid allocation on paramilitary violence in base municipalities.

The remaining columns of Table III show that our results are robust to a wide variety of controls, including linear time trends by base and non-base regions, and a post-2001 indicator variable interacted with the base variable, which allows the level effect of U.S. assistance on

\footnotetext{
${ }^{25}$ Colombian municipalities are analogous to US counties, and departments are analogous to US states. There are 1,150 municipalities grouped into 32 departments.
} 
violence in base and non-base regions to vary for the period before and after 2001. This is important since Figure 2 indicates that both US military assistance and differential paramilitary attacks in base areas increased in the post-2001 era. We also control for a host of other municipal characteristics measured in the beginning of the sample period, interacted with year dummies, which accounts for any changes in violence induced by these characteristics that may also be correlated with U.S. military aid. The controls include: a 1988 urban indicator (measured as population over 10,000), since bases tend to be located in larger cities; the standard deviation of height, since ruggedness may differ across base and non-base regions; and coca cultivation in 2000, the year Plan Colombia was launched, since 11 of the base municipalities produce this drug crop over the sample period. ${ }^{26}$ We also include an indicator for whether municipalities produce or transport oil, since oil is Colombia's largest export, and oil price shocks have been shown to increase violence differentially in oil regions over this period (Dube and Vargas, 2008).

In addition, we address the serious concern that bases may have been built in regions with high levels of historical violence. If these locations have become flashpoints in the armed struggle, they may display greater violence responsiveness to any shock such as aid, for reasons that have little to do with resource sharing between the military and paramilitary groups. In columns (7)-(9) we control for historical violence levels from a separate data source, measured as total war-related casualties over 1975-1987 (scaled by municipal population in the beginning of our sample period), and find that our main results remain unchanged.

Finally, in columns (10)-(12), we consider the alternative hypothesis that U.S. military aid strengthens the government military disproportionately in base regions, and paramilitary attacks increase there simply because paramilitary groups follow the military into regions where the government is stronger. In this case, paramilitary attacks would increase because of the structural relationship between the paramilitary and military rather than the increase in foreign military aid. To examine this alternative hypothesis, we control for the lag of government attacks. The coefficients on this variable indicate that paramilitary attacks, government attacks and guerilla attacks are all higher in municipalities that had more government attacks in the previous period. This suggests that there is some persistence in conflict dynamics. However, the coefficient on the aid shock remains significant (and does not fall in magnitude) for current period paramilitary and government attacks even when this control is included, indicating that the structural relationship does not drive the main effect. ${ }^{27}$

\footnotetext{
${ }^{26}$ We control for coca cultivation in 2000 since this is the year in which Plan Colombia, a major anti-narcotics aid package, was launched. However, the results are robust to controlling for interactions with coca cultivation in 1994, which is the earliest year for which coca data is available.

${ }^{27}$ Since U.S. military aid from previous periods may affect current period conflict, we also tested for dynamic effects by interacting the base indicator with lagged U.S. military aid. These results, presented in appendix table A.II, indicate that the coefficient on the lag interaction term is smaller than the coefficient on the current period interaction term for paramilitary attacks, and both insignificant and smaller for government attacks. This sug-
} 


\subsection{Addressing endogeneity in U.S. aid allocation}

If U.S. military aid increases in response to differential violence in base regions, then endogeniety in the timing of U.S. military aid could also confound our effects. Given the asymmetry of our main finding (of a significant effect on paramilitary attacks but not on guerilla attacks), a plausible account of the reverse causality would have to explain why changes in U.S. military funding respond to differential increases in paramilitary and government attacks, but not guerilla attacks. This seems counter-intuitive since the desire to achieve stability should lead U.S. military aid to respond to violence by the guerillas, who oppose the state. Nonetheless, to address this potential issue, we present results using our instrumental variables strategy in Table IV. Columns (1)-(3) show estimates of equation (3), which instruments the interaction of the base indicator and U.S. assistance to Colombia with the interaction of the base indicator with U.S. assistance to other nations outside of Latin America. Columns (4)-(6) also show the reduced form estimates. Both indicate that the results are robust to this IV strategy. In fact, comparing these coefficients to those in columns (1)-(3) of Table II demonstrates that the IV estimates are larger than the OLS estimates. The IV coefficients suggest that a $1 \%$ increase in aid translates into $3 \%$ more paramilitary attacks and $2.5 \%$ more government attacks in base municipalities versus non-base municipalities. This finding is consistent with the idea that OLS downward biases the estimates since U.S. funding responds to differential increases in violence in non-base municipalities, such as regions cultivating substantial amounts of coca.

Next, we account for the possibility that U.S. military aid allocation may be correlated with the strength of the Colombian state: if the Colombian government receives more aid when it spends more domestic resources on the conflict, and concentrates fighting efforts in base regions, then this could upward bias our estimates. In columns (1)-(6) of Table V, we control for (log) government military expenditures interacted with the base variable, using OLS and IV. Our main results remain unchanged. In columns (7)-(12), we control for various presidential administrations (which have differed in the degree to which they prioritized defense), interacted with the bases variable. The omitted category is President Virgilio Barco of the Liberal party, who served from 1986-1990. ${ }^{28}$ For example, the hallmark of the Uribe administration was putting greater resource toward suppressing the guerillas. However, the IV estimates are larger in magnitude after we include the administration controls, and these results indicate that most of the latter administrations witnessed relatively fewer paramilitary attacks in the base regions. These findings establish that our findings are not driven by a Uribe effect. ${ }^{29}$

gests that the contemporaneous effect is more important than the lag effect. Thus we use the contemporaneous interaction for the remainder of the analysis.

${ }^{28}$ Presidents Gaviria and Samper were also of the Liberal Party, while President Pastrana (1998-2002) was from the Conservative Party. Álvaro Uribe (president from 2002-2010) is an Independent who helped establish the National Untiy Party.

${ }^{29}$ The OLS results appear to suggest that the aid shock does not affect government attacks significantly when 
In the Supporting Information Appendix, we show that our results are robust to three additional changes. Since we have a relatively small number treatment municipalities, we use leave-one-out estimation to show that the effects are not driven by any one base. An additional table on spatial heterogeneity (A.III) addresses concerns that non-base regions may not serve as good controls for base regions by partitioning the sample in a variety of ways, including whether the municipality had a paramilitary presence in the beginning of the sample period, borders a base municipality, and is recorded as growing coca. In Table A.IV, we also improve the control set by presenting three "matching" estimators, where base and non-base municipalities are matched on population, municipal spending, area, altitude, secondary schooling, and coca cultivation. Both tables confirm that the results are robust to these alternative control sets.

\subsection{Aid, Military Operations and Coca Cultivation}

The long-standing stated aim of US military assistance to Colombia has been promoting counter-narcotics efforts and lowering drug crop production. However, after 2001, the U.S. government authorized the use of military assistance toward counter-insurgency ends in this country. To investigate what types of activity U.S. aid influences, in Table VI, we analyze the effect of the aid shock on different types of operations undertaken by the Colombian military, as well as overall levels of municipal coca cultivation. Because we look at the coca outcome, we restrict the sample to the set of municipal year observations for which the coca variable is available, but the results do not change if we analyze the military operations for the full sample. In columns (1)-(3), we look at counter-insurgency operations, including the number of armed group captives taken by the Colombian military, the number of weapons seized (which includes recaptured arms and deactivated explosives), and the number of kidnap victims rescued and freed from the illegal armed groups. The coefficient on our treatment variable is significant and positive for all of these variables, indicating that an increase in US aid differentially increases the number of counter-insurgency operations undertaken in military base municipalities. The effects imply that a $1 \%$ increase in U.S. aid increases captives taken by .9\%, increases arms seizures by $1 \%$ and increases freed and rescued kidnaps by .7\% more in base regions.

In columns (4)-(5) of Table VI, we analyze municipal coca cultivation and the number of counter-narcotics operations undertaken by the Colombian military. For the coca outcome, the

military expenditure is accounted for, and doesn't significantly affect any of the dependent variables when the administration dummies are included. However, this is likely to reflect overcontrolling, since U.S. military aid is likely to vary with idiosyncratic relationships among various Colombian presidents and the United States, and controlling for unrestricted presidential effects eliminates a lot of this variation in aid. If presidents are also pursuing distinct base-specific counterinsurgency strategies that affect only paramilitary groups, then including the presidential controls would confound the OLS estimates. However, the robustness of our estimates to the IV strategy assures us that this potential source of bias does not invalidate our account; endogenous time-varying U.S. military aid is exactly the kind of problem that the IV estimate solves. 
coefficient on the aid interaction is close to zero and statistically insignificant, which suggests that aid does not have a significant effect on drug crop production in the base regions. Moreover, this coefficient is negative and significant for the anti-narcotics operations, and substantial in magnitude: a $1 \%$ increase in aid implies that anti-narcotics operations fall by $2 \%$ more in base municipalities. In other words, when US military aid increases, there is a decrease in counternarcotics operations in base regions relative to non-base areas. One interpretation of this effect is that it reflects a shift from counter-narcotics to counter-insurgency in the use of U.S. military aid. Since most coca may not be cultivated in municipalities with military bases, in columns (6), we re-analyze the anti-narcotics operations for the set of municipalities that have been known to produce coca at some point, which includes 11 military base municipalities. The results remain effectively unchanged with this sample restriction.

\subsection{Aid, Assassinations and Electoral Participation}

Tables II-V have shown that allocation of U.S. aid through Colombian military bases has no significant effect on guerilla attacks but leads to significant increases in paramilitary attacks. To see if this rising violence is consistent with the political goals of the armed groups, we next analyze whether the aid shock has differential effects on paramilitary and guerilla violence during election periods. We analyze total homicides undertaken by various armed groups, and look specifically at political assassinations, a sub-category that includes the killing of elected officials, candidates and community leaders, and thus reflects political targeting.

Columns (1)-(4) of Table VII presents estimates of equation (4) for total homicides. Column 1 shows that, while the military aid shock has no significant effect on homicides during non-election years, it leads to a significant differential increase on homicides conducted by paramilitaries in election years relative to non-election years. Adding the coefficients together in the first two rows gives the total effect of the aid shock in election years. While positive, the noisiness of the coefficient in the second row does not allow us to rule out a zero effect of the aid shock on total paramilitary homicides in election years in the OLS estimates. However, when IV is used in column 3, the effect is positive, significant, and much larger, indicating that the aid shock leads to significant increases in homicides during election years. As in previous tables, there is no effect on homicides committed by guerillas, either in election or non-election years.

The second panel of Table VII looks specifically at assassinations. Once again the positive estimate of $\theta$, the coefficient on the three-way interaction in the first row, indicates that there is a differential effect of the aid shock on paramilitary assassinations in election years, relative to non-election years. However, the estimate of $\lambda$ (in the second row) indicates the aid shock has a negative effect on assassinations in non-election years. Moreover, the sum of the estimates 
of $\theta$ and $\lambda$ is also negative, indicating a negative effect of the aid shock on assassinations in election years. In other words, the aid shock reduces paramilitary political assassinations, but this reduction is smaller during election periods, relative to non-election periods.

Overall, these results suggest that the influx of U.S. military aid has a composition effect on the type of violence employed by paramilitary groups. During election periods, there is an increase in total paramilitary homicides, but a substitution away from assassinations, which are the highest profile killings. In other words, the "security effect" of U.S. aid may reduce the incentives to pursue assassinations, so that there are in fact fewer targeted killings of political leaders in base municipalities when U.S. aid rises. However, while U.S. aid induces a substitution away from assassinations, this effect is attenuated during election years, when the net political returns to violence against candidates and politicians is arguably highest. Columns 6 and 8 show that once again, there is no differential effect on guerilla assassinations during election periods. This suggests that to the extent that U.S. aid induces a composition effect on the nature of homicides, it exerts this influence solely on paramilitaries, not on guerrillas.

The significant increases in paramilitary homicides and assassinations during election periods is consistent with the idea that U.S. aid allocation strengthens paramilitary capacity to carry out politically targeted attacks. Additional resources may also strengthen the ability of paramilitary groups to pursue their electoral agenda. To examine this hypothesis, we analyze whether aid allocation through military bases also affects participation in local elections, since intimidating voters is a third dimension of paramilitary capacity. While we would ideally have data on which local parties were pro-paramilitary, and estimate the effect on those parties' vote shares, we do not have this information at the local level. Thus, we focus on voter turnout, and assess whether changes in US military assistance affect turnout differentially in municipalities with military bases, estimating equation (1) with log of total votes cast in the election as the outcome variable.

Table VIII presents the estimates on the aid interaction for the four local elections: gubernatorial elections and state elections, which take place at the department level, and mayoral elections and town council elections, which take place at the municipal level. Voter turnout data for local elections that is comparable across years is only available for the post-2000 period. This restricts our analysis to the years 2000 and 2003. Columns (1)-(4) show that the coefficients on the aid interaction is negative and significant, which suggests that an increase in US military aid differentially lowers turnout in base regions, for all four elections. These coefficients are elasticities and imply that a $1 \%$ increase in aid reduces turnout by $.09 \%$ for the governors and state assembly elections, and by .05\% and .08\% for the mayor and town council elections.

If reduced turnout reflects intimidation of voters by armed groups, we should see larger effects in contested regions, where the returns to reducing turnout will be larger. To explore 
this idea, we examine whether the effects are larger in municipalities that were either electorally contested or militarily contested. ${ }^{30}$ We classify a municipality as militarily contested if it experienced clashes between the guerillas and the government or the guerillas and the paramilitary during each of the years over 1995-1997. ${ }^{31}$ Column (5)-(12) of Table VIII show the effect of the aid shock on turnout in the militarily contested regions, and the uncontested regions. The results indicate that the aid interaction has a substantial negative effect on voter turnout in all 4 types of elections held in contested regions, and that these coefficients are much larger than the average effect for the full sample. For example, a $1 \%$ increase in foreign aid is predicted to reduce turnout for gubernatorial elections by .3\% and for mayoral elections by $.2 \%$. In contrast, the treatment has no significant effect on gubernatorial and mayoral election turnout in the uncontested regions. There is a significant reduction in turnout for state assembly and town council elections, but the magnitude of the coefficients are about half relative to those in the contested sample.

In Table IX, we partition the sample along lines of electoral contestation, based on whether an election was close in the previous (1997) regional election. A close election is defined as one in which the vote difference between the top two candidates was less than 5 percent. For our sample, it is meaningful to think of close elections only for the mayoral race. ${ }^{32}$ Columns (1)-(3) show the results for the effect on turnout in these municipalities. Column (1) includes all 155 electorally contested municipalities; column (2) subdivides further and looks at just the 11 municipalities that were both electorally and militarily contested; and column (3) looks at the 288 electorally contested municipalities that were not militarily contested. The coefficient is negative and significant in all three specifications, and all three coefficients are larger relative to those from the full sample (in Table VIII), which establishes that the aid shock reduces turnout more in contested regions. However, the coefficient is largest for the municipalities that are contested along both dimensions (in the second column). ${ }^{33}$

\footnotetext{
${ }^{30}$ There are two reasons why the effect may also be larger in militarily contested regions. First, a municipality may be militarily contested because there are large potential gains from control over this area. (For example, it might be located in a strategic corridor or be endowed with resources that can help finance armed activity). In this case, the armed group has larger expected gains from having an allied candidate in office. Alternatively, a municipality may be militarily contested if underlying preferences are polarized - i.e., it is a municipality where both the guerillas and the paramilitaries receive support from some fraction of the local population. In this case, military contestation should be strongly correlated with electoral contestation, and the higher marginal expected return from reducing turnout could motivate targeting of these regions.

${ }^{31}$ We choose the 1995-1997 period since our election sample begins in 2000, and the previous election took place in 1997. We avoid using a later interval since these clashes may be undertaken in anticipation of the elections in 2000. However, our results are insensitive to the choice of time period, and we get similar effects if we define contestation over 1997-1999.

${ }^{32}$ Multiple candidates are elected to both the state assembly and town council elections, and a close gubernatorial election is defined at the department level, while we analyze turnout at the municipal level.

${ }^{33}$ It is also worth noting that out of 56 militarily contested municipalities, and 155 electorally contested municipalities, only 11 appear in both groups. Indeed, the raw correlation coefficient between these two measures of contestation is actually negative. This provides suggestive evidence that municipalities are militarily contested
} 
Columns (4)-(6) of Table IX show the equivalent specifications for the non-contested municipalities. The coefficient on the aid interaction is insignificant in all three specifications, indicating that there is differential targeting of regions that are electorally contested. It is worth noting that the coefficient is close to zero (-.002) in column (6), which is the sub-sample of municipalities that are neither electorally nor militarily contested. In contrast, the coefficient is much larger (.1), albeit insignificant, in column (5), which is restricted to the set of militarily contested municipalities which were not electorally contested. This pattern suggests that both electoral and military contestation matter, but electoral contestation plays a particularly important role in determining the extent to which a rise in U.S. military aid is associated with lower electoral participation in base municipalities.

\section{Conclusion}

Although advanced countries transfer substantial resources to developing countries in the form of military assistance, little empirical work has evaluated the impact of military aid. This paper has estimated the effect of U.S. military assistance on conflict and electoral participation in Colombia, a country torn apart by civil war over the past four decades. We exploit the channeling of U.S. aid to army brigades, which are headquartered at bases in particular municipalities, to obtain within-country spatial variation in the allocation of military assistance. Using highly disaggregated conflict data from 1988-2005, we find that increases in U.S. military aid increased attacks by paramilitary groups differentially in municipalities containing military bases. In contrast, we find no significant effect on guerilla attacks. We interpret this finding as consistent with the well-documented collusion that takes place between the Colombian military and paramilitaries in fighting the guerillas. These results are robust to specifications, sub-samples, and an instrumental variables strategy based on worldwide increases in U.S. military aid (outside of Latin America). The coefficient estimates imply that the average annual increase of $92 \%$ in U.S. military aid to Colombia is associated with $138 \%$ more paramilitary attacks per year in base regions, relative to non-base regions during this period.

Turning to the implications for Colombian politics, we first document that there are more paramilitary homicides during election periods when U.S. military aid is high in base regions, and that this aid shock leads to differential paramilitary assassinations of politicians and community leaders in election periods relative to non-election periods. As before, we find no corresponding increase in guerilla political assassinations. We also find that voter turnout falls more in base municipalities when U.S. military assistance rises, which we interpret as a consequence

for reasons beyond the underlying preferences of the population, and that military contestation is based on factors that differ from electoral contestation. 
of increased paramilitary capacity to intimidate voters and reduce electoral participation. Consistent with this interpretation, the fall in turnout is larger in base municipalities that were previously contested either militarily or electorally, which are the regions where armed actors benefit the most from having an allied elected official, or where the return from intimidating voters is greatest for achieving political control.

Though we focus on Colombia, our results speak to broad questions in political development and international assistance. Military aid is sometimes proposed as a cure for the weak state, as it is presumed to enhance the government's repressive capacity, and facilitate its ability to secure a "monopoly on the legitimate use of violence." Yet our results suggest that, in environments such as Colombia, where there is collusion between the military and illegal armed groups, international military assistance can strengthen armed non-state actors, who rival the government over the use of violence. Our findings also document a channel through which foreign military aid can undermine formal democratic institutions, namely, by equipping organizations that use violence to manipulate elections.

The analysis in this paper holds a clear policy implication: it suggests that advanced nations should consider the informal links between the armed forces and illegal armed groups prior to deploying military aid to other conflict-torn societies, such as Iraq, Afghanistan, Mexico, or Indonesia. In these nations, similar collusion between the military and informal armed militias have led to the use of foreign military resources by illegitimate armed groups, and sometimes been accompanied by severe human rights abuses. Massacres in East Timor preceding the 1999 referendum on independence from Indonesia were led by militias tightly connected to the Indonesian military, which has been a large recipient of U.S. military assistance. In contemporary Iraq, informal Shiite militias conduct joint operations with the U.S. backed Iraqi army against suspected insurgents, despite accusations of torture and other human rights violations. The United States is currently contemplating a large increase in military aid to Mexico to assist in combating the well-armed private armies of drug cartels. However, a 2000 Global Exchange report notes that "the Mexican army has been infiltrated by narcotics traffickers at the highest ranks, and is increasingly dependent on U.S. weapons, training, and ideology (p. 46)." Taking account of the relationship between the state's armed forces and non-state armed groups could thus be an important pre-requisite for the effective deployment of military aid. 


\section{References}

Acemoglu, Daron, James Robinson and Rafael J. Santos-Villagran. 2010. "The Monopoly of Violence: Evidence from Colombia." Mimeo, MIT.

Angrist, Joshua D., and Adriana Kugler. 2008. "Rural Windfall or a New Resource Curse? Coca, Income and Civil Conflict in Colombia." The Review of Economics and Statistics, 90(2): 191-215.

Berman, Eli, Joseph Felter and Jacob Shapiro. 2009. "Can Hearts and Minds be Bought? The Economics of Counterinsurgency in Iraq." Mimeo, UCSD.

Berman, Eli and David Laitin. forthcoming. "Religion, Terrorism and Public Goods: Testing the Club Model." Journal of Public Economics.

Bjørnskov, Christian. 2009. "Do Elites Benefit From Democracy and Foreign Aid in Developing Countries?" Journal of Development Economics, Forthcoming.

Busso, Matias, John DiNardo and Justin McCrary. 2009. "New Evidence on the Finite Sample Properties of Propensity Score Matching and Reweighting Estimators." IZA Working Paper No. 3998.

Collier, Paul and Anke Hoeffler. 2002. "Aid, Policy and Peace: Reducing The Risks of Civil Conflict." Defence and Peace Economics, 13(6): 435-450.

Collier, Paul, and Anke Hoeffler. 1998. "On Economic Causes of Civil War: Oxford Economic Papers, 50: 563-573.

Collier, Paul, and Anke Hoeffler. 2004. "Greed and Grievance in Civil War." Oxford Economic Papers, 56: 563-595.

Collier, Paul and Anke Hoeffler. 2007. "Unintended Consequences: Does Aid Promote Arms Races?" Oxford Bulletin of Economics and Statistics, 69(1): 1-27.

Congressional Budget Justification for Foreign Operations. 2008. Joint Document of the State Department and USAID.

De Ree, Joppe and Eleonora Nillesen. 2009. "Aiding Violence Or Peace? The Impact of Foreign Aid on The Risk of Civil Conflict In Sub-Saharan Africa." Journal of Development Economics, 88(2): 301-313.

Djankov, Simeon, Jose Montalvo, and Marta Reynal-Querol. 2008. "The Curse of Aid." Journal of Economic Growth, 13(3): 169-194.

Dube, Oeindrila and Juan Vargas. 2008. "Commodity Price Shocks and Civil Conflict: Evidence from Colombia." Mimeo, Harvard University.

Easterly, William, Daniel Berger, and Shanker Satyanath. 2008. "Superpower Interventions and Their Consequences For Democracy: An Empirical Inquiry." NBER Working Paper No. 13992.

Deininger, Klaus. 2003. "Causes and Consequences of Civil Strife: Micro-Level Evidence 
from Uganda." Oxford Economic Papers, 55: 579-606.

Do, Quy-Toan, and Lakshmi Iyer. 2007. "Poverty, Social Divisions and Conflict in Nepal." HBS Working Paper 07-065.

Dunning, Thad. 2004. "Conditioning the Effects of Aid: Cold War Politics, Donor Credibility, and Democracy in Africa." International Organization 58(2): 409-123.

Fearon, James D. 2005. "Primary Commodities Exports and Civil War." Journal of Conflict Resolution, 49(4): 483-507.

Fearon, James D., and David Laitin. 2003. "Ethnicity, Insurgency, and Civil War." American Political Science Review, 97(1): 75-90.

Finkel, Steven, Aníbal Pérez-Liñn, and Mitchell Seligson. 2007. "The Effects of US Foreign Assistance on Democracy Building, 1990-2003." World Politics, 59(3): 404-439.

Freedman, David and Richard Berk. 2008. "Weighting Regressions by Propensity Scores" Evaluation Review. 32(4): 392-409.

Global Exchange. 2000. Always Near, Always Far: The Armed Forces in Mexico. Mexico, D.F.

Grossman, Herschel. 1992. "Foreign Aid and Insurrection." Defence and Peace Economics, 3(4): 275-288.

Goldsmith, Arthur A. 2001. "Foreign Aid and Statehood in Africa." International Organization, 55(1): 123-148.

Hidalgo, Daniel F., Suresh Naidu, Simeon Nichter and Neal Richardson. Forthcoming. "Occupational Choices: Economic Determinants of Land Invasions." Review of Economics and Statistics.

Hristov, Jasmin. 2009. Blood and Capital: The Paramilitarization of Colombia. Ohio: University Center For International Studies.

Isacson, Adam. 2005. "The U.S. military in the war on drugs." In C. Youngers and E. Rosin, editors, Drugs and Democracy in Latin America: The Impact of US Policy, pages 15-61. Lynne Rienner Publishers.

Jackson, Robert. 1990. Quasi-states:Sovereignty, International Relations, and the Third World. Cambridge University Press.

Knack, Stephen. 2004. "Does Foreign Aid Promote Democracy?" International Studies Quarterly, 48: 251-266.

Miguel, Edward, Shanker Satyanath, and Ernest Sergenti. 2004. "Economic Shocks and Civil Conflict: An Instrumental Variables Approach." Journal of Political Economy, 112(4): 725-753.

Morrison, Kevin. 2009. "Oil, Nontax Revenue, and the Redistributional Foundations of Regime Stability." International Organization, 63: 107-138. 
Remmer, Karen. 2004. "Does Foreign Aid Promote the Expansion of Government" American Journal of Political Science, 48(1): 77-92.

Restrepo, Jorge, Mike Spagat, and Juan Vargas. 2004. "The Dynamics of the Colombian Civil Conflict: A New Data Set." Homo Oeconomicus, 21(2): 396-428.

Sambanis, Nicholas. 2002. "A Review of Recent Advances and Future Directions in the Quantitative Literature on Civil War." Defense and Peace Economics, 13(2): 215-243.

Svensson, Jakob. 2000. "Foreign Aid and Rent-Seeking." Journal of International Economics, 51(2): 437-461.

Westad, Odd Arne. 2005. The Global Cold War: Third World Interventions and The Making of Our Times. Cambridge University Press.

Wright, Joseph. 2004. "How Foreign Aid Can Foster Democratization in Authoritarian Regimes." American Journal of Political Science, 53(3): 552-571. 
Paramilitary attacks

Government attacks

Guerilla attacks

Paramilitary homicides

Guerilla homicides

Paramilitary assassinations

Guerilla assassinations

Log votes Gubernatorial elections

Log votes State Assembly elections

Log votes Mayor's elections

Log votes Town Council elections

Coca, 1000's hectares cultivated

Log population

Captives

Weapons Seized

Freed Kidnaps

Anti-narcotics Operations

Sum casualties 1975-1987, per capita

Sum paramilitary attacks 1875-1987, per capita

Sum government attacks 1975-1987, per capita

Sum guerilla attacks 1975-1987, per capita

Standard Deviation of height

Mean height

Ever produced coca indicator

Coca in 2000, 1000's hectares cultivated

Oil production or pipeline indicator

Electorally contested, mayoral election 1997

Militarily contested

Log Real US military and narcotics aid to Colombia

Log Real US development aid to Colombia

Log Real US military aid to non-Latin American nations
Table I

Summary Statistics

Non-Base Municipalities

Base Municipalities

\begin{tabular}{|c|c|c|c|c|c|}
\hline \\
\hline \multicolumn{6}{|c|}{ Panel Level } \\
\hline Obs. & Mean & Std. Dev & Obs. & Mean & Std. Dev \\
\hline 16272 & 0.093 & 0.464 & 576 & 0.380 & 1.187 \\
\hline 16272 & 0.106 & 0.524 & 576 & 0.368 & 1.083 \\
\hline 16272 & 0.536 & 1.533 & 576 & 2.163 & 4.292 \\
\hline 16272 & 0.989 & 4.474 & 576 & 11.632 & 23.639 \\
\hline 16272 & 0.181 & 0.680 & 576 & 0.477 & 1.086 \\
\hline 16272 & 0.151 & 0.777 & 576 & 1.401 & 3.908 \\
\hline 16272 & 0.026 & 0.199 & 576 & 0.056 & 0.264 \\
\hline 1801 & 8.456 & 0.980 & 60 & 10.583 & 1.461 \\
\hline 1803 & 8.471 & 0.983 & 62 & 10.551 & 1.429 \\
\hline 1542 & 8.556 & 0.908 & 61 & 10.742 & 1.552 \\
\hline 1791 & 8.500 & 0.926 & 64 & 10.671 & 1.552 \\
\hline 7212 & 0.116 & 0.758 & 255 & 0.116 & 0.534 \\
\hline 16148 & 9.614 & 0.939 & 575 & 11.802 & 1.582 \\
\hline 16272 & 1.442 & 5.070 & 576 & 28.514 & 57.560 \\
\hline 16272 & 0.357 & 1.656 & 576 & 2.064 & 4.718 \\
\hline 16272 & 0.455 & 1.248 & 576 & 3.431 & 5.807 \\
\hline 16272 & 0.143 & 0.747 & 576 & 1.830 & 4.015 \\
\hline \multicolumn{6}{|c|}{ Municipal Level } \\
\hline 890 & 0.383 & 0.993 & 32 & 0.233 & 0.666 \\
\hline 890 & 0.004 & 0.040 & 32 & 0.006 & 0.029 \\
\hline 890 & 0.008 & 0.032 & 32 & 0.009 & 0.027 \\
\hline 890 & 0.082 & 0.216 & 32 & 0.036 & 0.102 \\
\hline 903 & 364.948 & 260.479 & 32 & 319.362 & 339.043 \\
\hline 903 & 1320.408 & 952.889 & 32 & 925.442 & 930.323 \\
\hline 904 & 0.267 & 0.442 & 32 & 0.344 & 0.483 \\
\hline 904 & 0.169 & 1.105 & 32 & 0.199 & 0.948 \\
\hline 904 & 0.247 & 0.431 & 32 & 0.375 & 0.492 \\
\hline 817 & 0.196 & 0.397 & 32 & 0.313 & 0.471 \\
\hline 904 & 0.069 & 0.253 & 32 & 0.094 & 0.296 \\
\hline
\end{tabular}

Annual Level

$\begin{array}{cc}-2.198 & 1.187 \\ 0.009 & 0.028 \\ 1.540 & 0.185\end{array}$




\section{Table II}

\section{US Military Aid and Violence: OLS Estimates}

Log US Military Aid X Base

Log US Development Aid X Base
(2)

(1)

Paramilitary

\begin{tabular}{ccc} 
attacks & attacks & attacks \\
\hline $0.148^{* *}$ & $0.125^{* *}$ & -0.082 \\
{$[0.061]$} & {$[0.060]$} & {$[0.111]$}
\end{tabular}

(4)

Paramilitary Government Guerilla

attacks attacks attacks

\begin{tabular}{ccc}
\hline- & - & - \\
- & - & -
\end{tabular}

$\begin{array}{ccc}0.915 & -0.384 & 2.513 \\ {[1.815]} & {[0.943]} & {[4.146]}\end{array}$

Observations

16723

16723

16723

16723

16723

16723

Number of municipalities

936

936

936

936

936

936

Notes. Variables not shown include municipality and year fixed effects and log of population. Robust standard errors clustered at the municipality level are shown in parentheses. *** is significant at the $1 \%$ level, ** is significant at the $5 \%$ level, * is significant at the $10 \%$ level. 


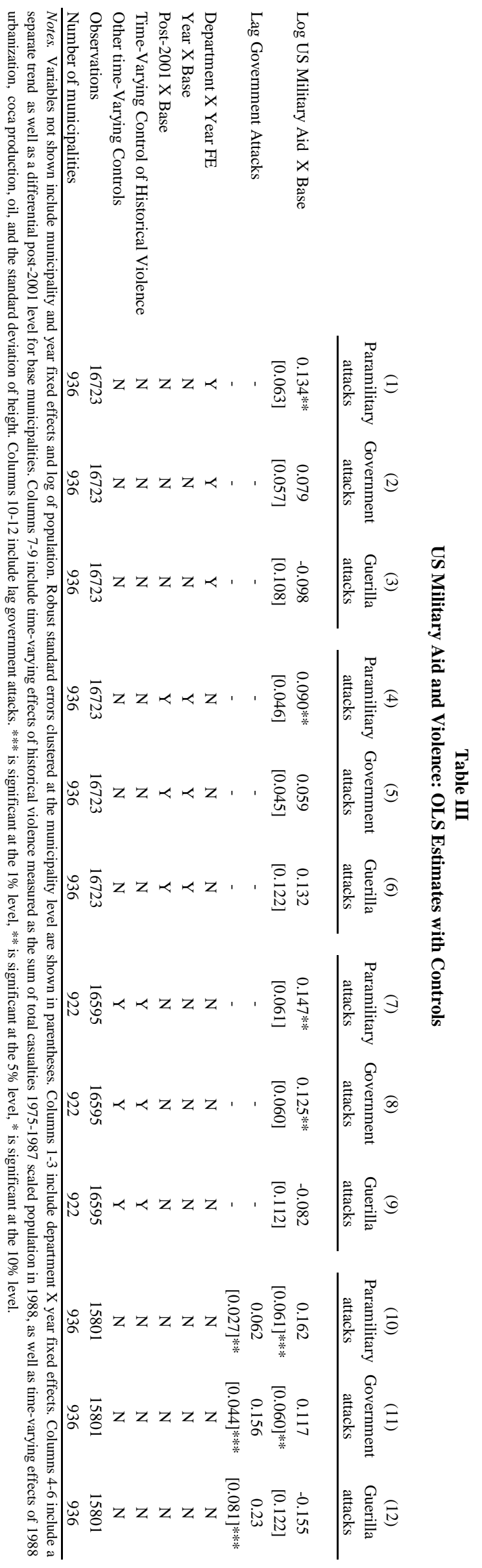




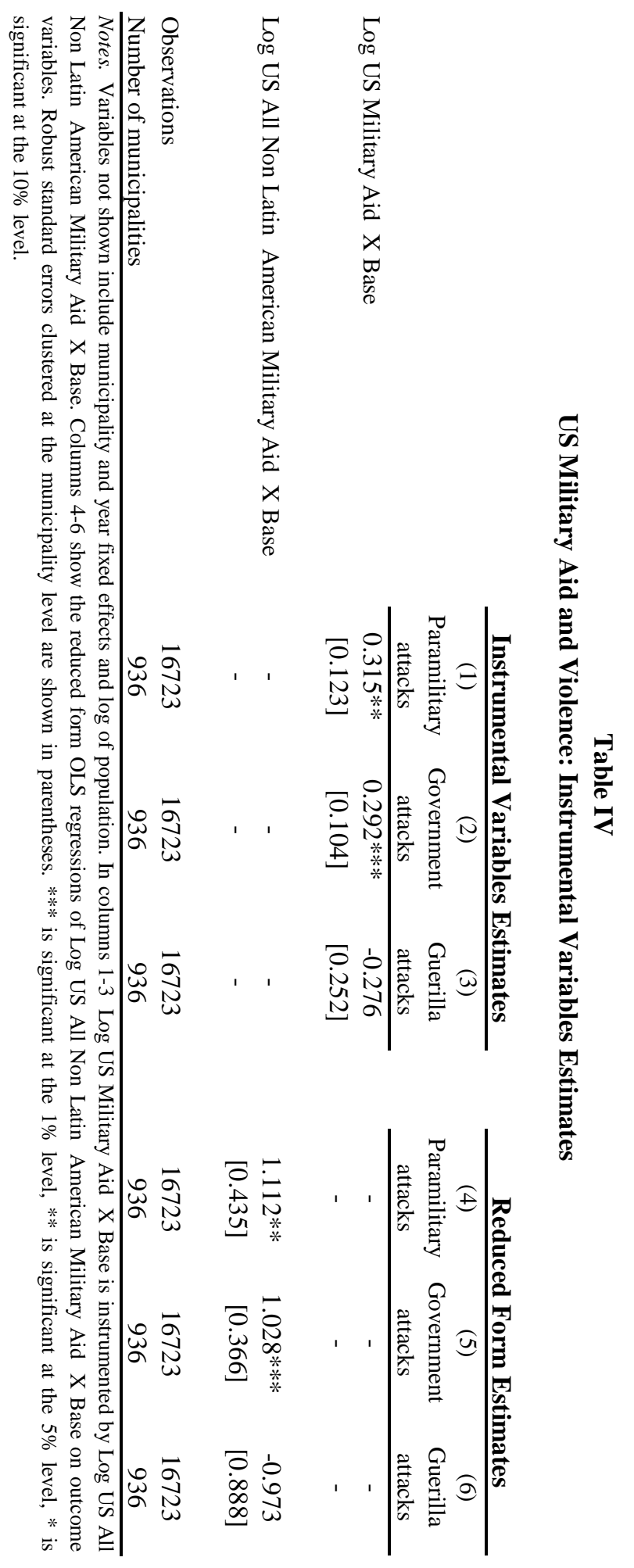




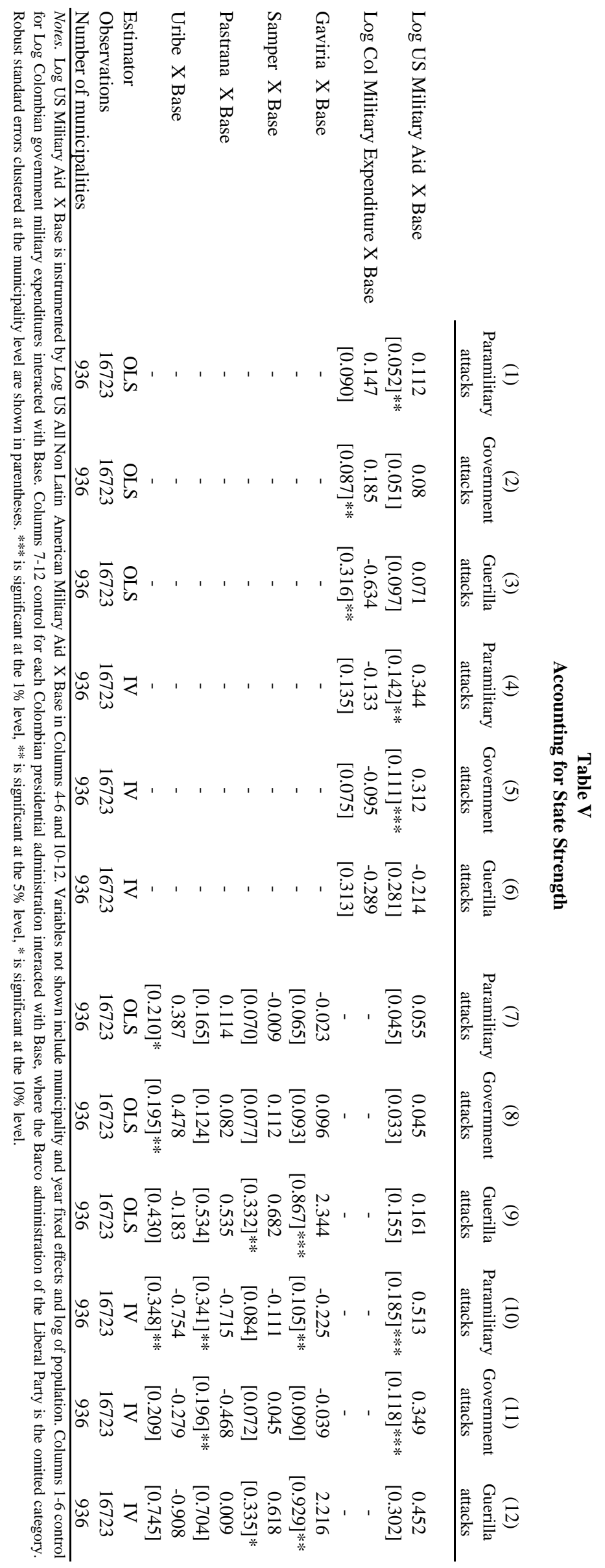




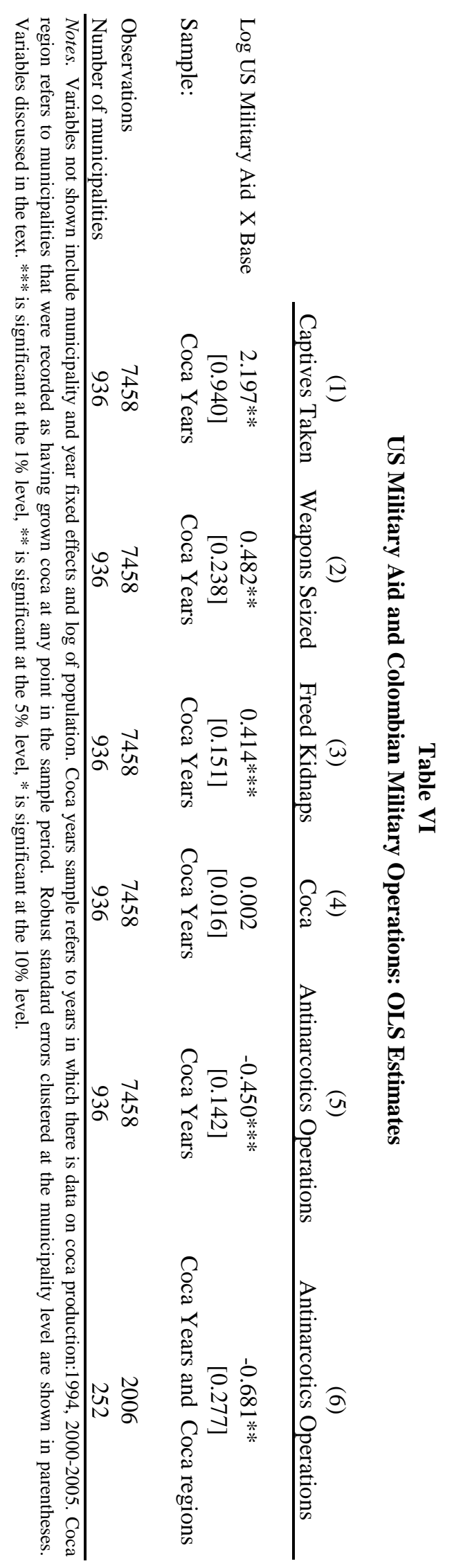




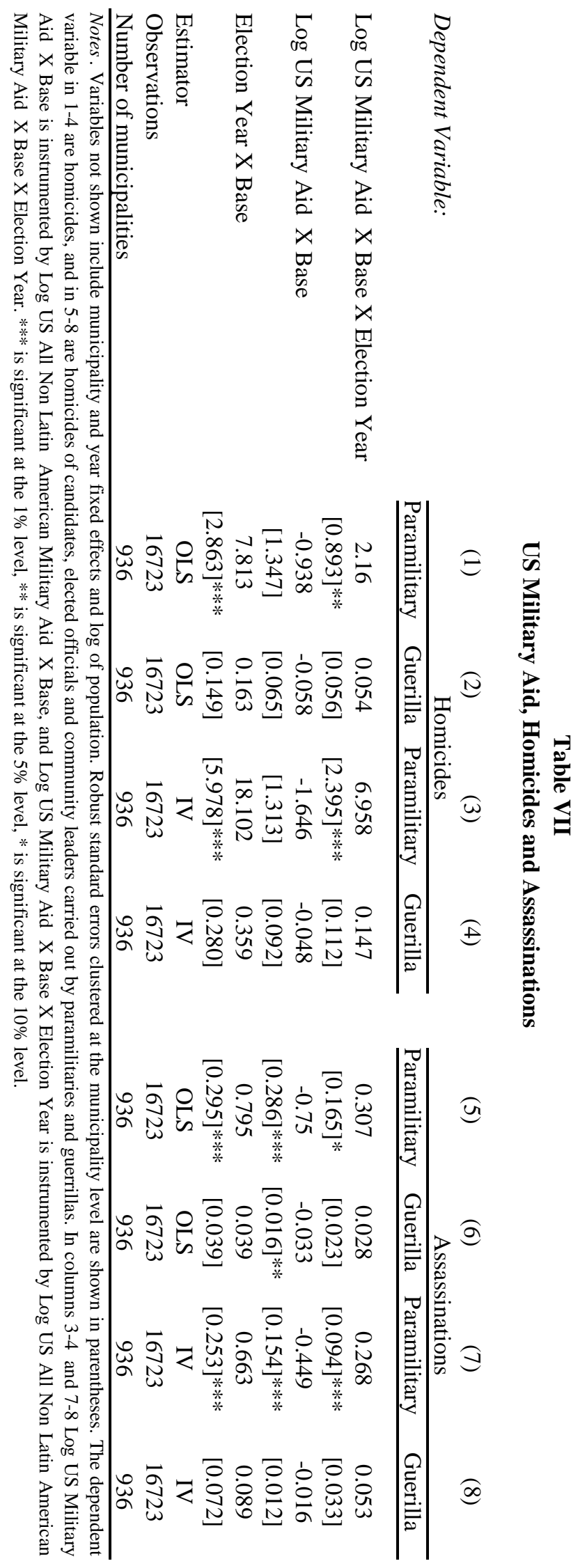




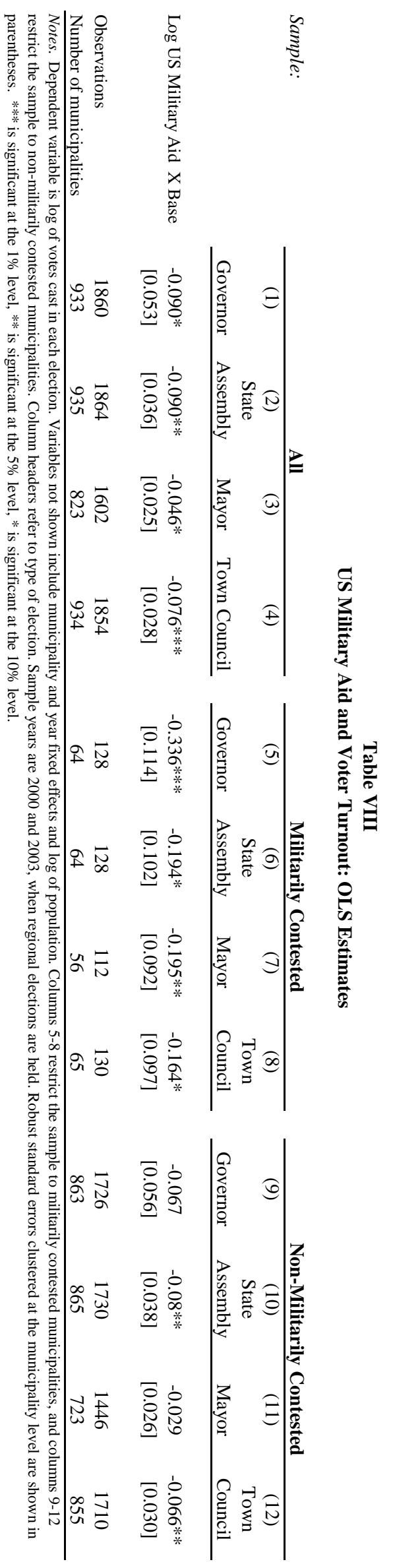


Table IX

US Military Aid and Voter Turnout in Electorally Contested Areas: OLS Estimates

Sample:

Subsample:

Log US Military Aid X Base

\begin{tabular}{ccc}
\multicolumn{3}{c}{ Electorally Contested } \\
\hline & Mon \\
All & Military & Military \\
Contested & Contested
\end{tabular}

(1)

$$
\begin{array}{ccc}
-0.128 * * * & -0.444 * * * & -0.087^{* * *} \\
{[0.040} & {[0.100]} & {[0.036]}
\end{array}
$$

(2)
(3)
22

288

144

11

Votes for Mayoral Election

Non-Electorally Contested

Non

Military Military

All Contested Contested

(4)

(5)

(6)

$-0.012$

$-0.1$

$-0.002$

[0.029]

[0.097]

[0.031]

\begin{tabular}{lcccccc} 
Observations & 310 & 22 & 288 & 1210 & 88 & 1122 \\
Number of municipalities & 155 & 11 & 144 & 605 & 44 & 561 \\
\hline
\end{tabular}

Notes. Variables not shown include municipality and year fixed effects and log of population. Column headers refer to type of election. Sample years are 2000 and 2003, when regional elections happen. A municipality is militarily contested if it experienced either governmentguerilla clashes or paramilitary-guerilla clashes every year between 1995 and 1997 inclusive; it is electorally contested if the vote difference between the top two mayoral candidates was less than 5\% during the previous elections in 1997. Robust standard errors clustered at the municipality level are shown in parentheses. ${ }^{* * *}$ is significant at the $1 \%$ level, ** is significant at the $5 \%$ level, * is significant at the $10 \%$ level. 


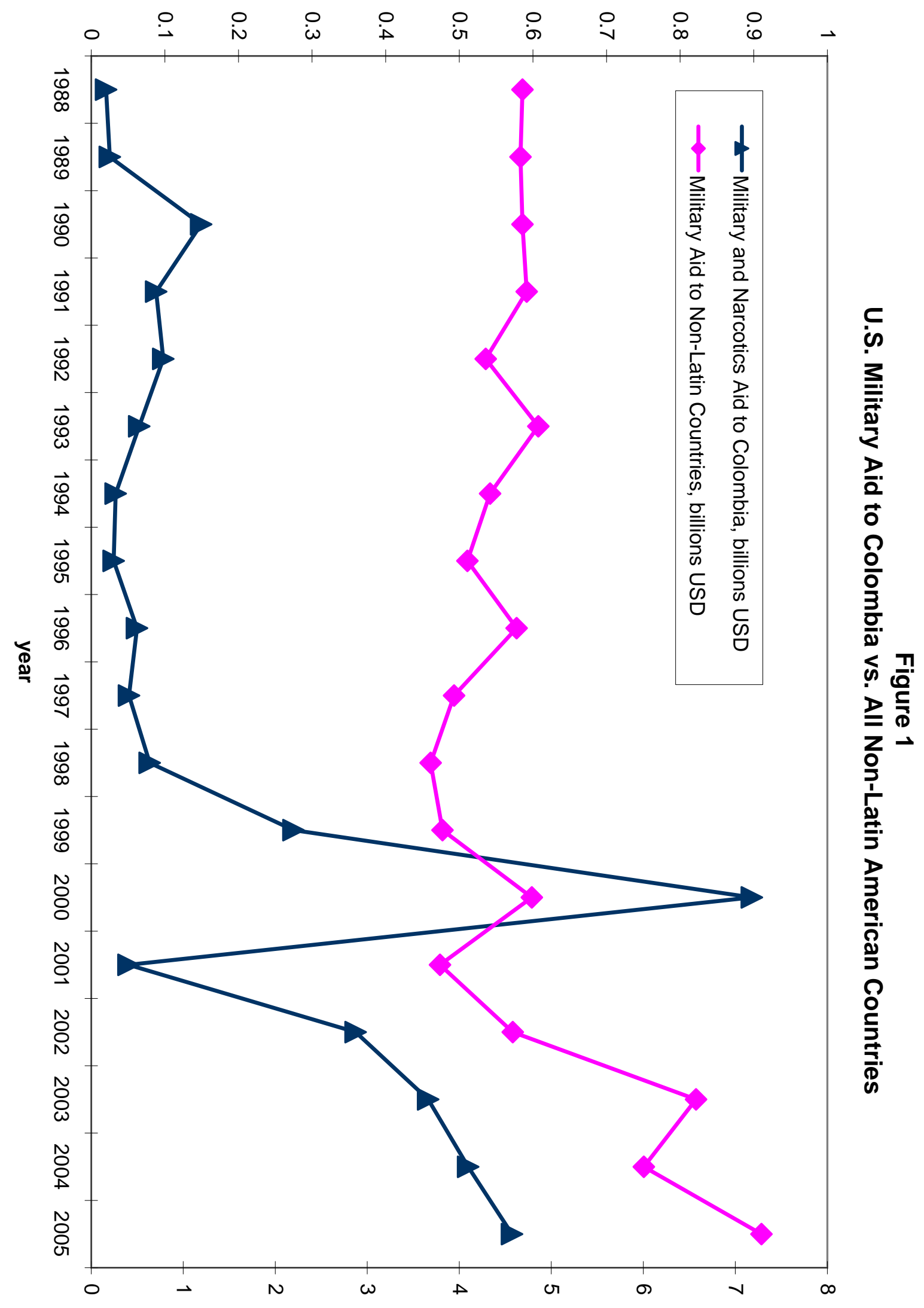




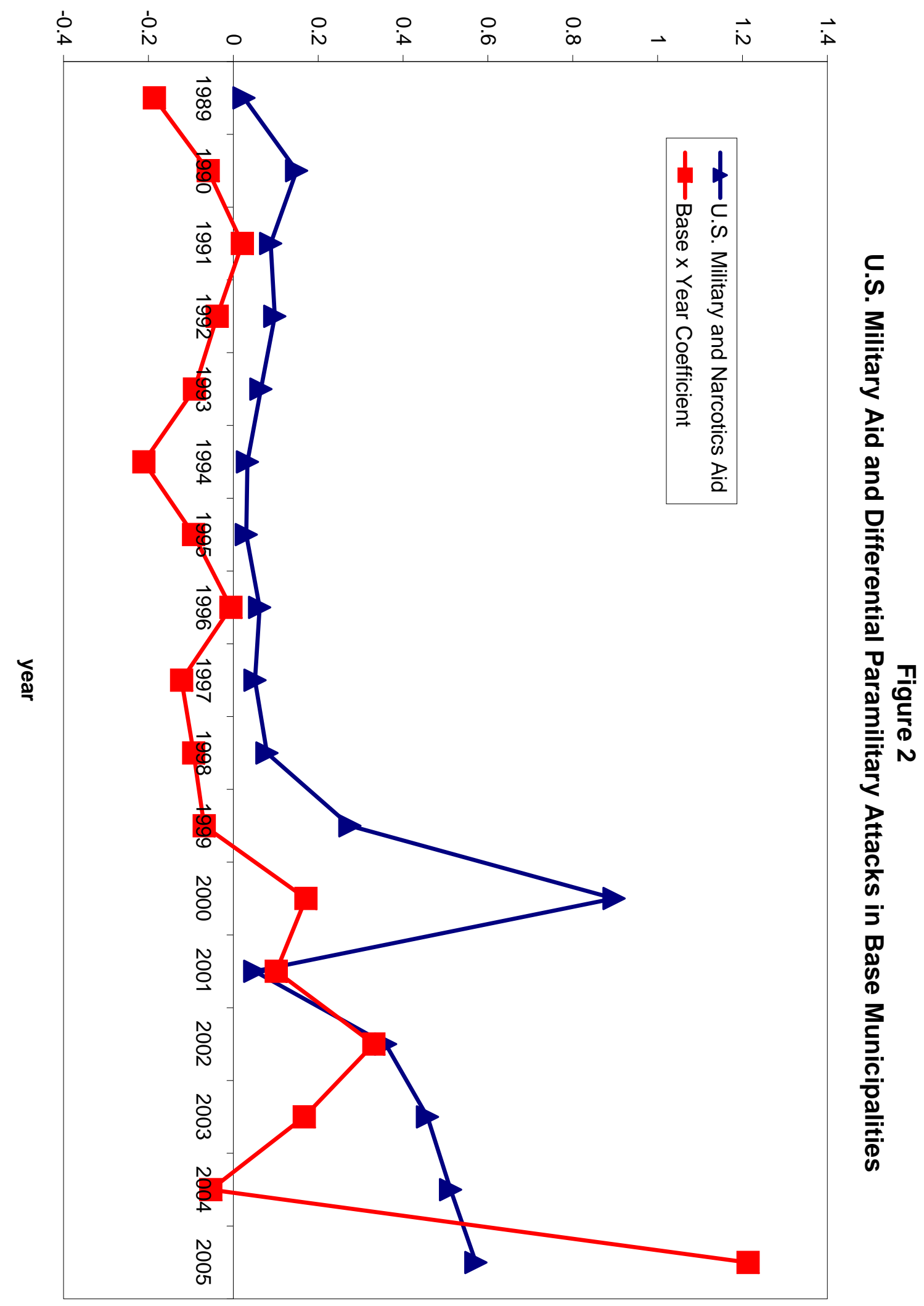


Map 1: Municipalities with Military Bases

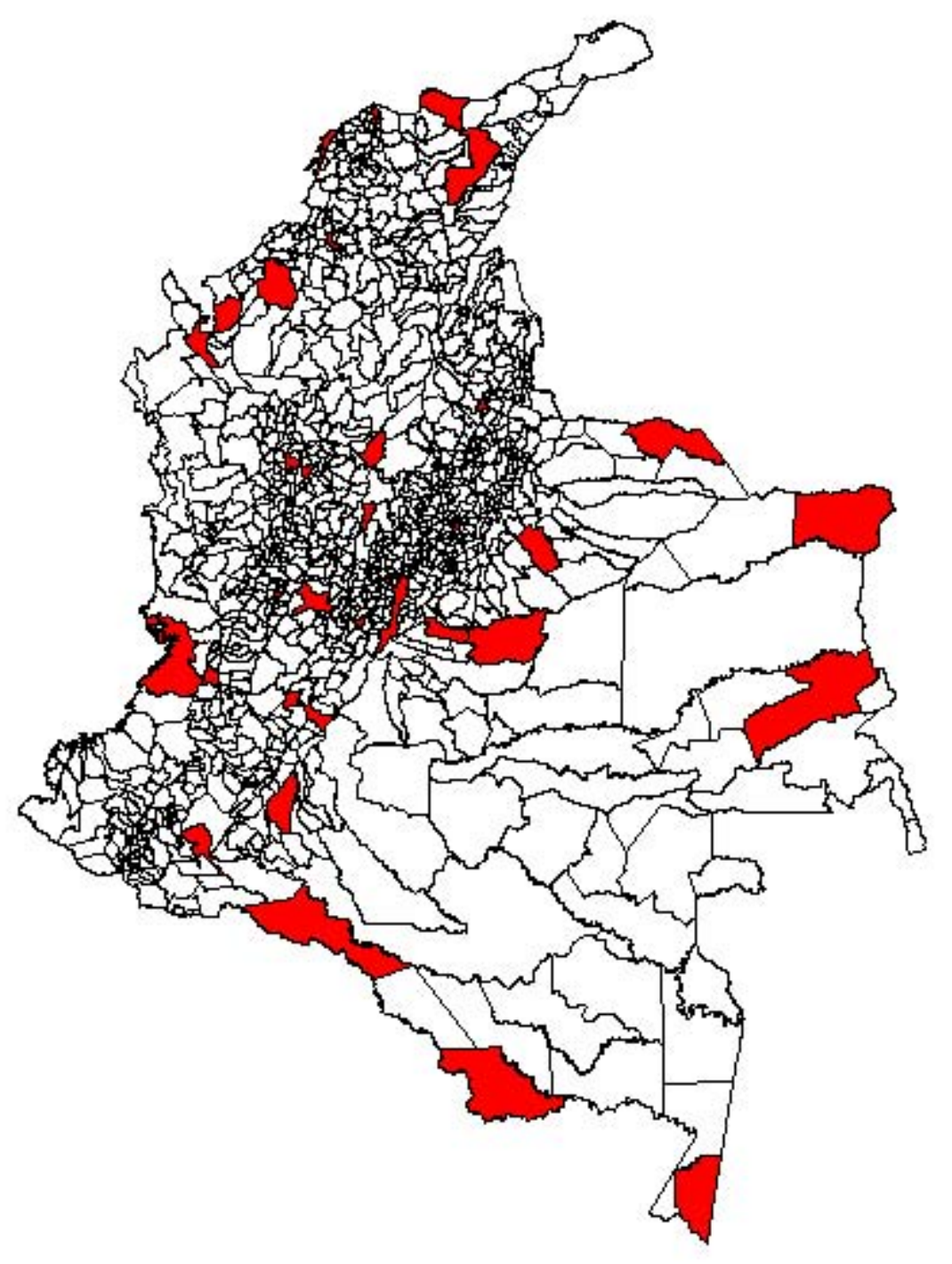




\section{Supporting Information Appendix}

\subsection{Leave-one-out estimation}

Our analysis uses a relatively small number of treatments regions (since 32 out of 936 municipalities have military bases). This raises concerns that the results may potentially be biased by an outlying treatment observation. To test the sensitivity of our estimates to individual municipalities, we re-estimate equation (1) 32 times, leaving out one of our base municipalities each time. This gives us 32 coefficients, the mean of which is .147. (The minimum is .111 and the maximum is.166). Figure A.1 gives the density of the T-scores of each of these regressions, which shows that the lowest T-score is 2.1, and that the coefficient is significant at the $95 \%$ level, regardless of which individual base municipality is excluded. ${ }^{1}$

\subsection{Accounting for Spatial Heterogeneity}

Our empirical strategy compares changes in violence in municipalities with and without bases as US funding changes, and therefore presumes that the regions without bases serve as good controls for regions with bases. However, if regions with and without military bases differ from one another in terms of characteristics that determine conflict responsiveness, this spatial heterogeneity may confound our estimates.

In Table A.III, we attempt to improve the set of control municipalities by partitioning the sample in different ways. We present these results for just paramilitary and government attacks, since the aid interaction remains insignificant in all specifications where guerilla attacks is the dependent variable. In columns (1)-(2), we restrict the sample to municipalities which had a paramilitary presence in the beginning of the sample period, defined as whether the municipality experienced any type of paramilitary activity in each of the first three years between 1988 and 1990. Activity is not just limited to paramilitary attacks, but additionally includes events such as population displacement, kidnaps, blocked transport routes, and pirating or theft undertaken by paramilitary groups. We choose the three year window because activity in any one year may reflect a transitory or idiosyncratic incursion, but sustained activity over a three year period is a better indicator of persistent or more endemic paramilitary presence.

This restriction creates a subset of 224 municipalities (out of 936 in the baseline sample), and includes 22 of the 32 treatment regions with military bases. The coefficients on the aid interaction remain positive and significant for both paramilitary and government attacks, and

\footnotetext{
${ }^{1}$ Our results are also robust to using the Conley-Taber estimator, which adjusts the standard errors for a small number of treatment groups in difference-in-differences type estimation, such as the one employed in our analysis. However, we do not report these results as the Conley-Taber estimator does not adjust for arbitrary heteroskedastcity.
} 
insignificant for guerilla attacks, even when we restrict attention to this more comparable subset. In columns (3)-(4), we look at the regions without paramilitary presence in early years. The insignificant coefficient on paramilitary attacks may reflect the fact that regions without a paramilitary presence in the beginning of the sample period continue to have low paramilitary presence throughout the sample period. ${ }^{2}$ Alternatively, it may also reflect low power in treatment (as only 10 base municipalities are included in the sub-sample without a paramilitary presence).

Next, we partition the sample based on municipalities that do and do not border the municipalities with bases. If military bases have been constructed in strategic regions that are particularly responsive to violence, this raises the concern that overall increases in conflict correlated with US military spending may have resulted in greater violence in these flashpoints for reasons unrelated to the aid per se. From this angle, bordering municipalities may make for better controls in the sense that they are more likely to share the strategic municipal characteristics. As shown in columns (5)-(6), when restricted to the 210 neighboring municipalities, the coefficients on the aid interaction remain unchanged for both the paramilitary and government attack outcome variables. (For example, the estimated coefficient was .148 for the paramilitary attacks outcome in the baseline specification in Table II, and the equivalent coefficient is .133 in column (6) of Table A.III).

On the other hand, restricting attention to border regions also makes it more likely that increases in paramilitary activity in the base municipality arises from substitution away from non-base municipalities, since its less costly to relocate armed activity away from nearby regions. To explore this idea, in columns (7)-(8), we remove the neighboring regions from the control set. Again, the coefficients on the aid interaction effectively remain unchanged: for the paramilitary attacks outcome, the coefficient is .145. This suggests that the effect is not driven by substitution or a substantial lowering of paramilitary violence in the control regions. In addition, suggestive time series evidence indicates that at the annual level, as U.S. military aid increases, paramilitary attacks also increase. We show this simple regression in column (4) of Table A.I, and the significant coefficient confirms that there are net annual increases in attacks in years when funding increases. This suggests that even if the positive coefficient on the treatment interaction arises in part from substitution, the entire effect is not based on a simple re-allocation of paramilitary attacks from control to treatment regions. ${ }^{3}$

Finally, we partition the sample into regions with and without coca production in columns

\footnotetext{
${ }^{2}$ For example, mean paramilitary attacks is substantially lower in later years for the 712 municipalities without paramilitary presence in the beginning of the sample period.

${ }^{3}$ In columns (5)-(6) of Appendix Table I, we also present the simple regression of paramilitary attacks on the log of military aid separately for base and non-base regions, controlling only for municipality fixed effects and log population. The coefficients show that there is a significant relationship in both the base and non-base regions, but the effect is much larger in base regions. The difference in these coefficients is given by $\lambda$, the coefficient on the treatment interaction in equation (1).
} 
(9)-(12) of A.II. Given its stated anti-narcotics objective, U.S. military spending may have a differential effect on conflict in coca regions relative to non-coca regions. If military bases are located in regions cultivating coca, then it would be difficult to distinguish the effect of aid on violence that arises from the presence of a base, relative to the presence of drug crops. Indeed, 11 of the 32 bases are located in municipalities that have been recorded as producing coca. However, when we partition the sample, we find that the coefficient on the aid interaction remains highly significant for paramilitary and government attacks in the set of 684 municipalities that were recorded as never having produced coca over the sample period. This shows that the effect of US military aid on paramilitary violence does not arise solely though a coca-related channel. In contrast, the aid interaction becomes marginally insignificant for paramilitary attacks in the set of 252 municipalities that were recorded as having produced coca during at least one year of the sample. In addition, the coefficient for the aid interaction on government attacks becomes insignificant and falls sharply in magnitude in the coca sample relative to the non-coca sample. Since aid continues to exert an effect on paramilitary attacks but not government attacks in the coca region, one interpretation is that the military outsources more of its counter-insurgency efforts to paramilitaries in the drug crop regions, where the rule of law may be weaker, or where state capacity may be lower.

\subsection{Matched Estimates}

In Table A.IV, we improve the control set for base regions in a second way, by presenting three "matching" estimators. First, we estimate a cross sectional probit regression of the probability of being a base on fixed municipality characteristics, and obtain predicted propensity scores for the full sample. ${ }^{4}$ In columns (1)-(2), we estimate equation (1), restricting the sample to control municipalities with propensity scores at least as large as the smallest propensity score of the base municipalities, i.e., the common support of treatment and control units. In columns (3)-(4), we employ the full sample, but weight the regressions by the propensity score. ${ }^{5}$ In columns (5)-(6), we restrict the sample to control municipalities that are matched to the base municipalities by a 50-nearest neighbor match. The large number of neighbors is required to obtain balance on all the interactions and quadratics. The coefficient of interest remains significant at least the $10 \%$ level across all matching estimates, even when the matching procedure reduces the sample substantially. The results provide robust evidence that the influx of U.S. military aid

\footnotetext{
${ }^{4}$ The municipality characteristics are: 1988 population, log 1988 municipal spending, area, altitude, 1988 fraction with secondary schooling, and a coca growing dummy which equals 1 if the municipality was recorded to grow the coca drug crop any year of the sample period. Pair-wise interactions and quadratics of all variables are also included.

${ }^{5}$ The estimated propensity score has some very low and very high values, which challenges the assumption of strict overlap that justifies the use of propensity score re-weighting (Busso et al., 2009) and exacerbates random error (Freedman and Berk, 2008). Thus we winsorize the distribution of weights at the 5th and 95th percentiles.
} 
into base regions has no significant effect on guerilla attacks, but result in differential increases in paramilitary attacks. 


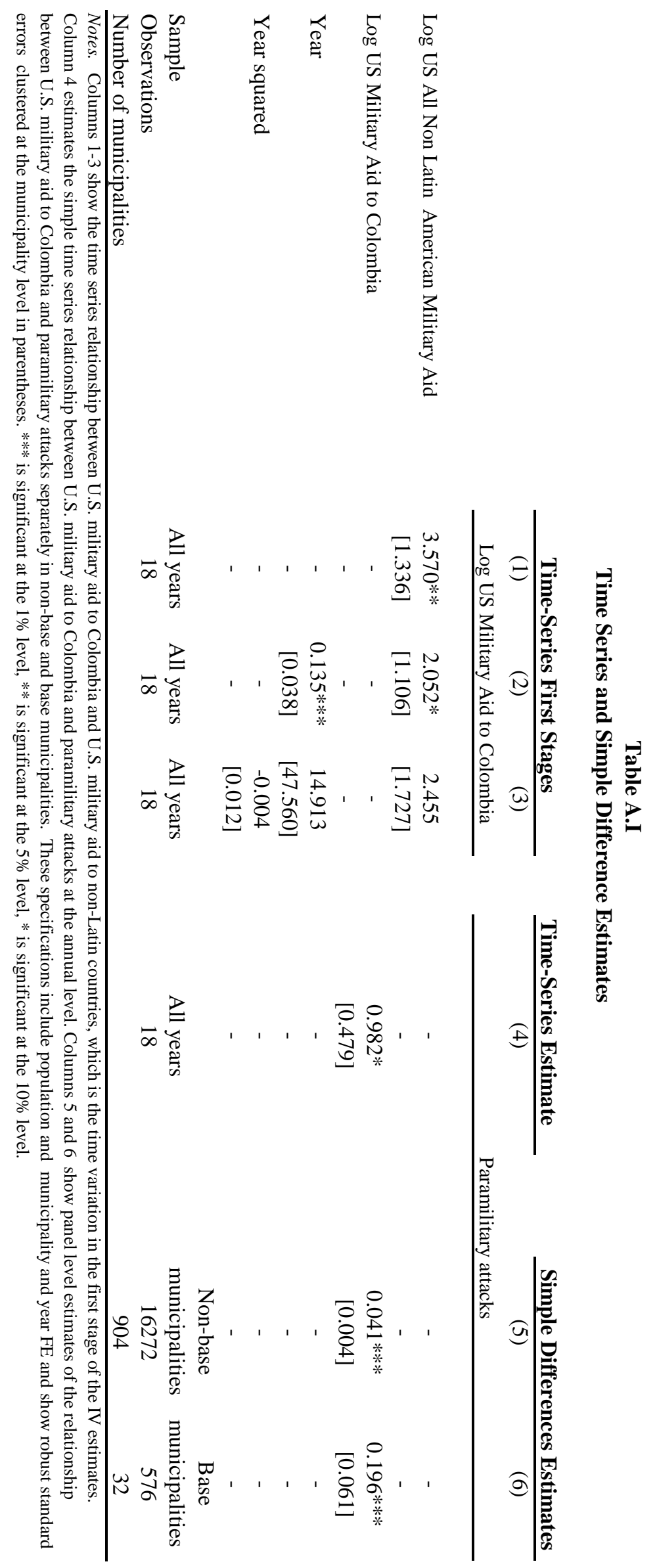


Table A.II

US Military Aid, Lag Aid and Violence: OLS Estimates

(1)

(2)

(3)

Paramilitary Government Guerilla

Log US Military Aid X Base

attacks attacks

attacks

$\begin{array}{ccc}0.125 & 0.105 & -0.177 \\ {[0.053]^{* *}} & {[0.058]^{*}} & {[0.136]} \\ 0.075 & 0.034 & 0.059 \\ {[0.041]^{*}} & {[0.033]} & {[0.078]}\end{array}$

Observations

15801

15801

15801

Number of municipalities

936

936

936

Notes. Variables not shown include municipality and year fixed effects and log of population. The second row shows coefficient estimates of the interaction of base with US military aid lagged by one year. Robust standard errors clustered at the municipality level are shown in parentheses. ${ }^{* * *}$ is significant at the $1 \%$ level, ${ }^{* *}$ is significant at the $5 \%$ level, * is significant at the $10 \%$ level. 


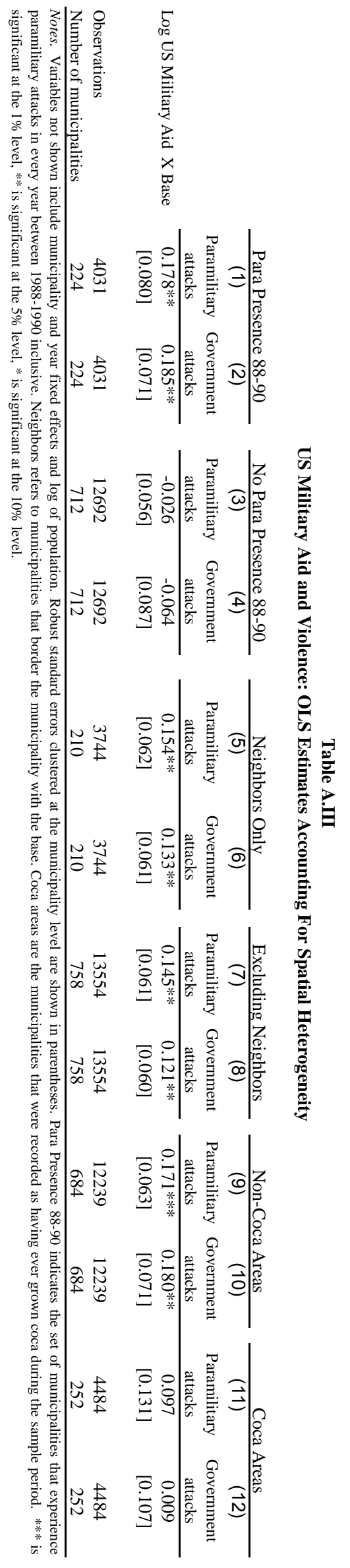


Table A.IV

US Military Aid and Violence: Matched Estimates

\begin{tabular}{|c|c|c|c|c|c|c|}
\hline & (1) & (2) & (3) & (4) & (5) & (6) \\
\hline & $\begin{array}{c}\text { Paramilitary } \\
\text { attacks }\end{array}$ & $\begin{array}{l}\text { Guerilla } \\
\text { attacks }\end{array}$ & $\begin{array}{c}\text { Paramilitary } \\
\text { attacks }\end{array}$ & $\begin{array}{l}\text { Guerilla } \\
\text { attacks }\end{array}$ & $\begin{array}{c}\text { Paramilitary } \\
\text { attacks }\end{array}$ & $\begin{array}{l}\text { Guerilla } \\
\text { attacks }\end{array}$ \\
\hline \multirow[t]{2}{*}{ Log US Military Aid X Base } & $0.122 *$ & -0.115 & $0.128 * *$ & -0.0750 & $0.109 *$ & -0.0490 \\
\hline & {$[0.0657]$} & [0.123] & {$[0.0568]$} & [0.112] & [0.0635] & [0.118] \\
\hline Estimator & \multicolumn{2}{|c|}{ Common Support } & \multicolumn{2}{|c|}{ Propensity Score } & \multicolumn{2}{|c|}{ Nearest Neighbors Match } \\
\hline Observations & 4985 & 4985 & 16723 & 16723 & 3563 & 3563 \\
\hline Number of municipalities & 277 & 277 & 936 & 936 & 198 & 198 \\
\hline
\end{tabular}

Notes. Variables not shown include municipality and year fixed effects and log of population. In columns 1-2, the sample is restricted to control municipalities with propensity scores at least as large as the smallest propensity score of the base municipalities. In columns 3-4, regressions are weighted with the propensity score (winsorized at the 5th and 95th percentiles). In columns 5-6, the sample is restricted to control municipalities matched to treatment municipalities using a 50 nearest neighbor match. Robust standard errors clustered at the municipality level are shown in parentheses. *** is significant at the $1 \%$ level, ** is significant at the $5 \%$ level, * is significant at the $10 \%$ level. 
Figure A.1: Density of T-Scores from OLS Leave-one-out Estimates

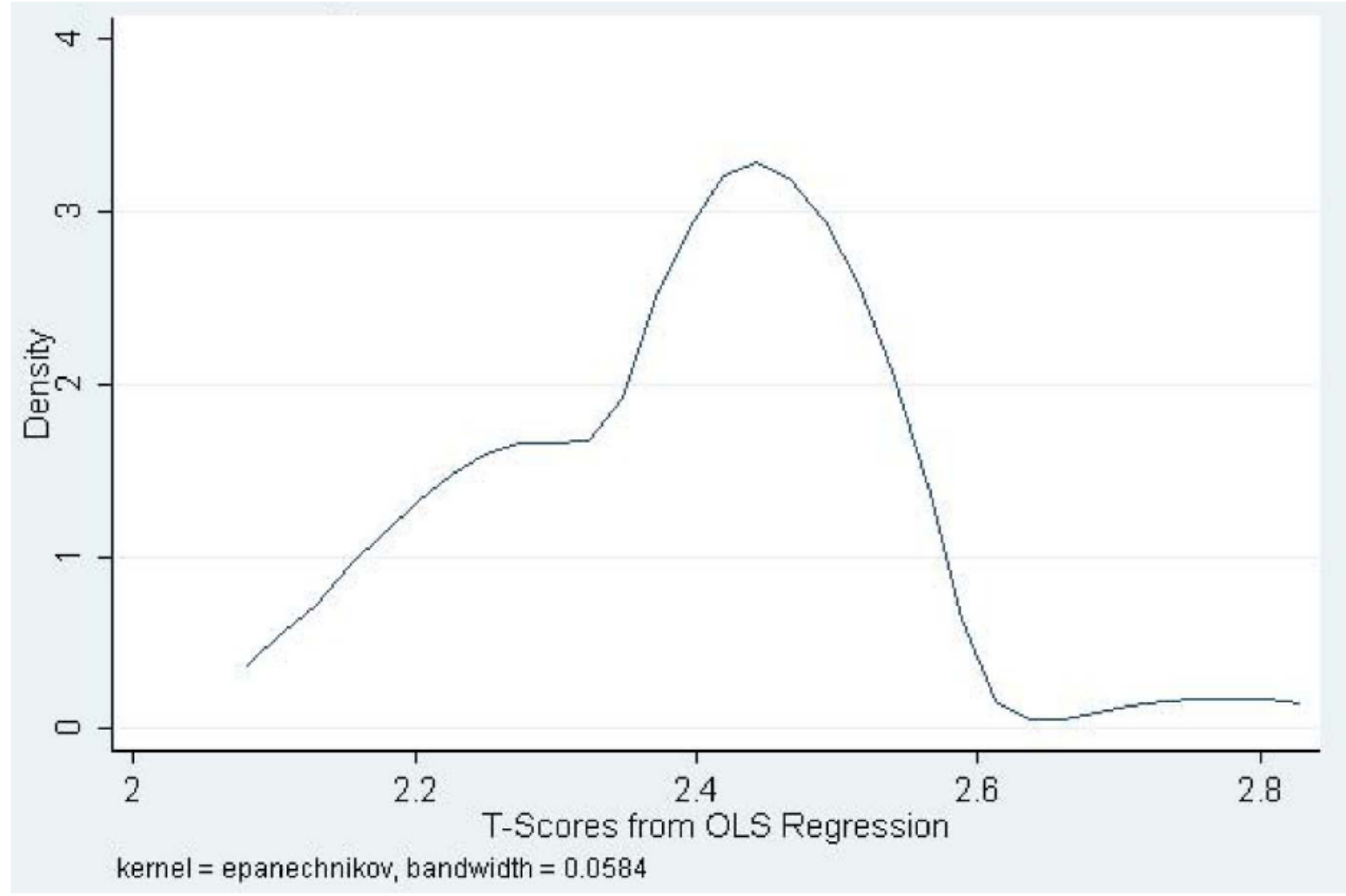

